\title{
PERCEIVED INDOOR ENVIRONMENTAL QUALITY OF HOSPITAL WARDS AND PATIENTS' OUTCOMES: A STUDY OF A GENERAL HOSPITAL, MINNA, NIGERIA
}

\author{
ALFA, M. T. ${ }^{*}-$ ÖZTÜRK, A. \\ Department of Architecture, Cyprus International University, Haspolat, via Mersin 10, Turkey \\ *Corresponding author \\ e-mail:mohammedtalfa@yahoo.com,malfa@ciu.edu.tr
}

(Received 24 ${ }^{\text {th }}$ Feb 2019; accepted $24^{\text {th }}$ May 2019)

\begin{abstract}
The objective of this study was to assess patients' perceptions of the indoor environment of wards in a hospital in terms of architectural design, thermal comfort, indoor air quality (IAQ), lighting and acoustical parameters. The study attempted to determine the factors influencing the perceived indoor environmental quality (PIEQ) and explored the relationships between the perceived importance of indoor environmental quality (PI-IEQ) and health recovery, health satisfaction and therapeutic ambience of the hospital. A field study of the indoor environmental quality (IEQ) of 4 wards in the General hospital at Minna, Niger state, Nigeria was conducted, and responses from 271 patients were obtained. Structural equation modelling was employed for data analysis. The research identified the six IEQ factors that influenced PIEQ as architectural design features, thermal comfort, adaptive opportunities, lighting, IAQ and acoustics aspects. PIEQ had a positive influence on a ward being perceived as conducive for wellbeing. It was observed that health satisfaction had the most significant and positive influence on PIIEQ. The second most positive influence was health recovery. Therapeutic ambience also had a positive influence on PI-IEQ but this was not significant.
\end{abstract}

Keywords: architectural design, thermal comfort, adaptive opportunities, lighting, indoor air quality, acoustics, health recovery, health satisfaction, hospital ward

\section{Introduction}

Indoor environmental quality (IEQ) as one of the features of green buildings and the sustainable environment has been drawing much attention, due to its high impact on the behaviour of the building users. An assessment of the (IEQ) of buildings is essential in determining success and failure. Buildings are designed and constructed to be occupied by people and the requirements for their occupancy must be made a prerequisite for their comfort. Therefore, the significance of sustaining better (IEQ) in buildings including hospital buildings should be a concern for architects, planners and stakeholders.

For buildings such as healthcare facilities, the issue of maintaining health and comfort should not be overlooked. In the practice of nursing, a healthy environment has been noted as having significant impacts on the health of the patient. This conforms to AlRajhi et al.'s (2010) notion who describe hospitals as diagnostic human treatment environments where activities such as care promotion, health education, training and research is undertaken. A hospital environment that contributes to healing does not only add to the patient's wellbeing, but also the wellbeing of the healthcare workers. It has been posited by Zborowsky and Kreitzer (2008) that hospital buildings which are comprised of adequate indoor environmental quality would attract, retain, and enhance the patient's healing process as well as the worker's efficiency. Therefore, a hospital facility should be designed to accommodate the maximum benefit to the occupants, namely patients, their family members, visitors, and healthcare workers. As such, the 
indoor environmental quality of a hospital facility is essential for its occupants. A poor (IEQ) create stressful feelings on the occupants' perception of their environment.

Similarly, research has shown that poor (IEQ) is associated with a negative impact on the occupants' physical and psychological health (Mahbob et al., 2011; Sadek and Nofal, 2013). Additionally, Sadek and Nofal (2013) remark that the impact of (IEQ) on patient's satisfaction affects psychological and physical dispositions. Thus, the design and settings of the indoor environment of hospitals should be designed to foster the emotional needs of patients, their families, and staff (Salonen et al., 2013).

The awareness for a healthy and comfortable work environment in buildings has not yet taken root or informed the design of healthcare facilities. This is because the pressure to create sustainable buildings has given more attention to the environmental aspects of the built form, and less to the health and wellbeing of occupants. Researchers, however, have begun to understand the need to focus on the sustainable environment for occupants (Smith and Pitt, 2011), and this should be the same for hospital facilities. Therefore, this paper identifies the influence of each factor affecting PIEQ and explores its relationship with health recovery, health satisfaction and therapeutic ambience on PI-IEQ.

\section{Background}

\section{Architectural design features}

Features of the hospital's architectural design include room size, design and furniture. Room size (dimensions, area and volume) is an essential factor that can affect the perception of patients. The design includes the shape of the walls, floor and ceiling. According to Kembel et al. (2014), hospital design and spatial configuration have an impact on patient recovery. Similarly, Scholz et al. (2019) suggest that room design influences patients' healing outcomes. For example, furniture in the hospital room, in particular flexible furniture has been shown to play a crucial role in meeting various health and recovery requirements (Huisman et al., 2012). Furniture criteria include type, design, postural comfort and ergonomics (Biancheri and Landi, 2017). In the context of health care settings, there are limited studies that have investigated the relationships between the spatial environment and patient recovery processes (Bosch and Lorusso, 2019). Other authors suggest that the configuration of the plan and the size of the hospital rooms may facilitate patient interaction and support medical care activities (Alfonsi et al., 2014; Mourshed and Zhao, 2012).

\section{Thermal comfort}

A thermally comfortable and healthy indoor environment for patients is essential for their optimum recovery. Thermal comfort describes the condition of the mind in terms of temperature satisfaction in a defined environment (ASHRAE, 2004a). Two important schools of thought exist in thermal convenience research; the heat balance approach (Fanger, 1970) and the adaptive thermal comfort approach (de Dear et al., 2013). Fanger (1970) introduced the concepts of the predicted mean vote (PMV) and predicted percentage of dissatisfied (PPD), which have been incorporated into the international standards (ISO, 2005) and ASHRAE (2004b). The adaptive principle opined that 'humans react in such a way that tends to lean towards ensuring that their comfort is reestablished when changes which affect their comfort level' occur (Nicol et al., 2012). The idea of adaptive thermal convenience, based on the adaptive principle and outcomes 
of several field studies, has been incorporated into ASHRAE (2004b) and CEN 15251 (2007). Several studies have investigated the physical quantities that affect the indoor thermal comfort of wards and also the effects of thermal comfort on patients (Khalid et al., 2019; Sadrizadeh et al., 2018; Shi et al., 2018; Verheyen et al., 2011). Such researches were carried out in naturally ventilated (NV) and air-conditioned (AC) wards using the heat balance approach and adaptive comfort models. Over time, studies have revealed that no specific temperature is ideal for people living in a particular building enclosure. However, although $20-24{ }^{\circ} \mathrm{C}$ has been judged as the range that is acceptable for healthy daily living, priority must be given to personal preferences or sentiments expressed by individuals. The level of activities and the choice of clothes also impacts on the thermal comfort of an individual (Djongyang et al., 2010; Gou et al., 2018; Kamalha et al., 2013).

Research outcomes related to indoor thermal comfort deals with the thermal environment acceptability of hospital wards and their level of compliance with global best practices (Khodakarami and Nasrollahi, 2012). Khalid et al. (2019) showed that the wellbeing of patients largely depends upon their preferences in terms of thermal comfort and air quality, and this should be considered. For example, the assessment of thermal comfort in a Belgian healthcare facility is set at $95 \%$ despite $29 \%$ of the thermal surrounding not being in accordance with ASHRAE design ranges of temperature and relative humidity (Verheyen et al., 2011). This situation implies that the environmental conditions of hospital patient rooms recommended by ASHRAE are sometimes very tough for patients to adapt to and suggests that perhaps the range of environmental parameters should be broadened.

Studies have shown that sensation, comfort and preferences in tropical countries are at variance with global standards (ASHRAE, 2007; ISO, 2005), which implies that thermal tolerance confronted in warm, humid season is greater, due to adaptation and acclimatisation (Anam, 2018). Therefore, greater efforts aimed at improving relevant and contextual thermal comfort that can consider varied outcomes, preferences and adaptation measures, for non-air conditioned spaces in tropical locations are required. Additionally, humans strive better under a cooler temperature that higher temperature (USEPA, 2015). This indicates that a relative rise in temperature also leads to the corresponding vaporisation of particulate matter from indoor components including furniture, fittings and building materials thereby limiting indoor thermal quality (Toftum, 2010). A varied number of factors impact room temperature ranging from fenestration opening that can increase thermal challenges during summer (Norbäck and Nordström, 2008). The architectural decision to design a well-ventilated in-patient ward, by utilising the outdoor environment should be of principal consideration in tropical countries. Accurate and adequate fenestration for ventilation and positioning of ceiling fans should also be evaluated and considered.

\section{Lighting}

The indoor environments of hospital buildings are highly demanding, with ambient parameters that are dependent upon use patterns, activities and specific sanitary needs. As a result, guaranteeing adequate comfort conditions becomes a more important and pressing issue than energy consumption (Ulrich et al., 2008), which has been regarded as a crucial factor for designing healing environments (Huisman et al., 2012). A welldesigned healing environment in healthcare can have a significant impact on health outcomes including reducing errors and infections (Joseph, 2006), improving patients' 
moods (Beute and Kort, 2014) and stress (Ulrich, 1991). Also, colour and lighting play a major part in the perceived health outcomes of patients (Dalke, 2006) in addition to adequate soundscape environments (Mackrill et al., 2014). This is achieved by providing high window-to-wall ratios that enhance daylighting parameters and result in visual comfort and energy savings in patients' rooms.

Improper use of roller shutters may darken the room to the detriment of health and wellbeing. Daylighting conditions, indoor illuminance levels and visibility from the room to the outside should be key considerations for work on energy retrofitting of hospitals (Calama-González et al., 2019). Choi et al. (2012) identified a significant relationship between indoor daylight environments and a patient's average length of stay in a hospital room. The study revealed that in addition to the seasonal weather factor, indoor illuminance and luminance ratios could potentially influence the design of hospital spaces. Benedetti et al. (2001) highlight the antidepressant effect of daylighting on occupants and conclude that direct exposure to natural sunlight may reduce a patient's length of stay in hospitals. Likewise, Raanaas et al. (2012) reveal that having views through the windows as opposed to partially or blocked views may help alleviate stress and shorten patients' stay in hospitals.

\section{Indoor air quality}

Hospitals represent a uniquely complex environment that differs from other commercial or residential buildings, given that its occupants are at a higher risk of health symptoms such as eye irritation, headaches, coughs, colds, dizziness, asthma, respiratory and cardiovascular diseases (Eames et al., 2009; Pérez-Padilla et al., 2010; Verde et al., 2015). Environmental microbes can contaminate the patient care environment and complicate recovery if users develop infections from common infectious agents. Therefore, good ventilation performance is important to achieve minimal exposure to infectious airborne microbes (Leung and Chan, 2006; Verde et al., 2015). Consequently, hospitals should be regarded as high-performance buildings in terms of environmental and air quality to enhance staff efficiency and maintain patients' healing process (Leung and Chan, 2006; Shrivastava et al., 2013; Verde et al., 2015; Wan et al., 2011).

Achieving clean indoor air quality within hospitals is important and requires a good understanding of how the ventilation systems, indoor occupants, type of medical activities, building materials, as well as spatial and seasonal variations affect indoor air pollution levels (Erdogan et al., 2010; Jung et al., 2015; Nimlyat and Kandar, 2015; Verde et al., 2015). Fenestration within the hospital building can allow for the inflow of polluted air from outdoor sources into the indoor environment of the hospitals. Likewise, evaporation of particulate matter from furniture, water and infiltration of radon and other gases from underlying soil and bedrock also contributes to the pollution of the indoor environment (John et al., 2010). Other factors that may contribute to poor IAQ include poor cleaning practices, poor moisture control (e.g. water leaks or persistent damp surfaces), human occupancy (e.g. odours) and poor building maintenance (Paevere et al., 2008).

\section{Acoustics}

The sound environment is a vital part of the overall environmental ecosystem, and sounds beyond the acceptable decibel level is unwanted (usually referred to as noise) and can be seen as a major environmental stressor in the clinical surrounding (Xie et al., 
2009). The impact of sensory stimuli such as sound and light is a critical challenge in creating a suitable environment in hospital settings for patients and operators. Research has shown that noise in the hospital environment can inhibit sleep and patient's recovery (Gardner et al., 2009; Hofhuis et al., 2012; Monsén and Edéll-Gustafsson, 2005; Waye et al., 2013; Xie et al., 2009). This suggests that unpleasant or distressing sounds impact negatively on the rate of recovery of patients in the hospital and in some extreme cases worsen the health condition of the patients. This includes psychological and physiological effects such as altered memory, increased agitation, aggressive behaviour, depression, anxiety, psychiatric disorders and deciphering speech difficulties (Elmenhorst et al., 2012; Helton et al., 2009; Joseph and Ulrich, 2007; Ryherdet al., 2008; Short et al., 2011). According to Frumkin and Louv (2007), it could be argued that people are closely attached to the natural world, which suggests that contact with nature is beneficial to health and wellbeing. As such, nature sounds may also be introduced in the environment as a positive distraction, which has been shown to have a significant influence on patients' clinical and behavioural outcomes (Pati and Nanda, 2011; Shepley, 2006).

\section{Adaptive opportunities}

Adaptive opportunities as defined by Nicol et al. (2012) are 'the chances created by structures for occupants to provide adequate comfort themselves such as windows, blinds, fans, etc.' The feedback approach suggested by Nicol and Humphreys (1973), relating to deductions from research on thermal comfort field surveys, targets feelings of high temperature or cold as a significant function of the comfort control system. And also further opined that poor sensation conditions the occupants to evolve basic measures, mitigation and modification that helps to stabilise the system. This approach to thermal comfort is generally termed an adaptive model (Nicol et al., 2012).

Adaptive actions cover the physiological, social and behavioural dimensions that enable occupants to start depending on their thermal environment (Yan et al., 2017; Kim et al., 2018). Such adaptive actions, among others, include switching on fans, opening a window, switching on the air conditioners and so on. An adaptive approach to thermal comfort targets the behaviour of the occupants who try to achieve their comfort. Brager et al. (2004) defined the imperatives of individual control, as an avenue to enhance the performance and promote the thermal satisfaction of the users. Gou, Lau, and Chen (2012) evaluated the occupants' dimension of management on the comparative note against building use studies (BUS) benchmarking system. Their study reveals a significant correlation between occupants' control of heating, cooling and ventilation with the thermal comfort, overall comfort and productivity, which are important components of IEQ.

\section{Theoretical predictions}

Based on the literature review on the various dimension of IEQ and exploratory factor analysis (EFA), the factors that influence PIEQ were identified, and a model was developed to explore the influence of PIEQ on patient's perception of a ward being conducive. The model also explored the influence of health satisfaction, health recovery and therapeutic ambience on PI-IEQ of the hospital. The final research model (Fig. 1) and hypotheses are proposed as follows. 


\section{Hypotheses}

Hypothesis 1 (H1): Patient satisfaction is enhanced with an enhanced level of PIEQ.

Hypothesis 2 (H2): An enhanced level of PIEQ of ward leads to an enhanced level of perception of the ward as being conducive for wellbeing.

Hypothesis 3 (H3): Health satisfaction, health recovery and therapeutic ambience has a positive influence of PI-IEQ.

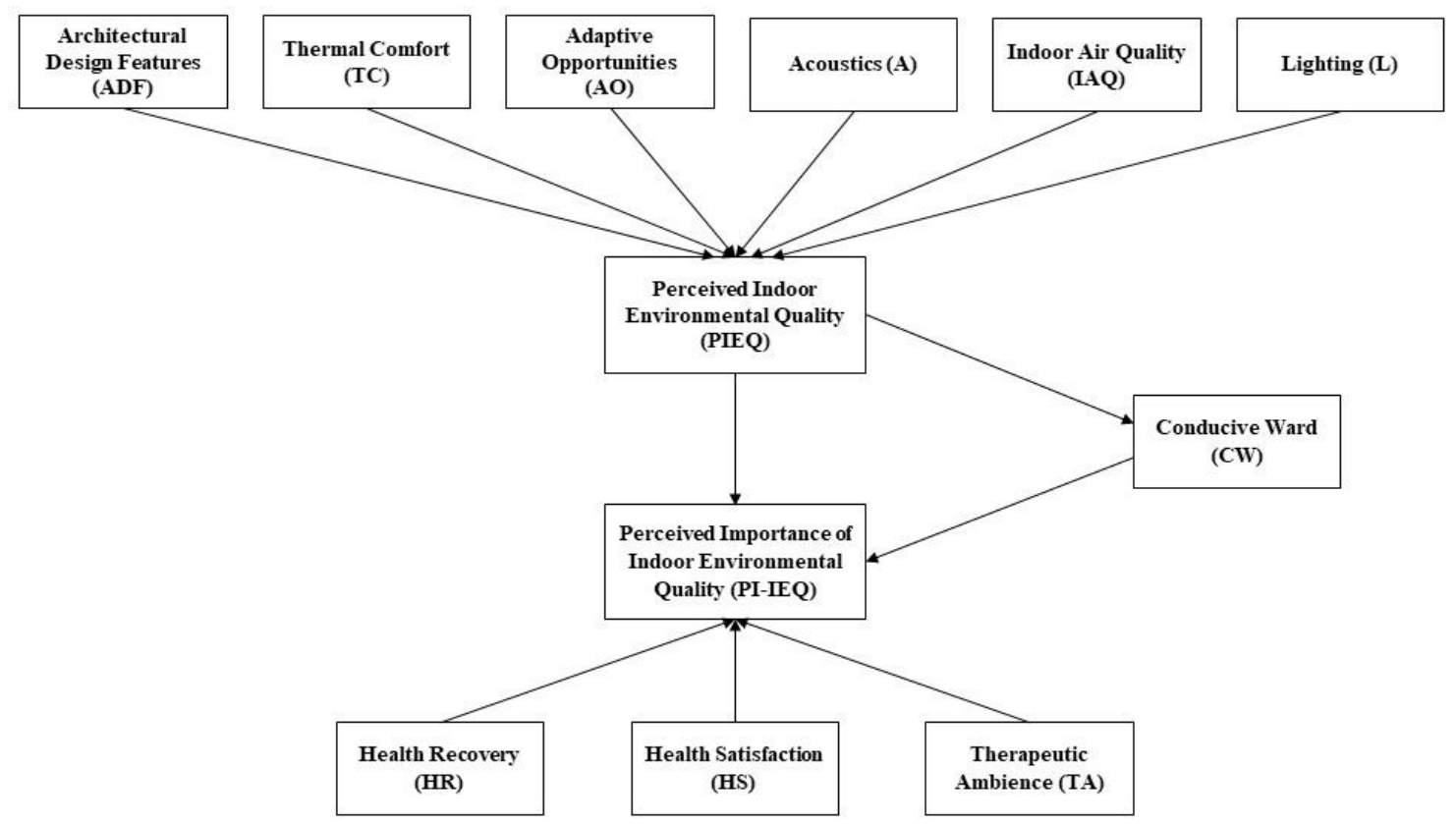

Figure 1. Research model

\section{Research methods}

\section{The study area}

This study is carried out in Minna, Niger State, which is the twelfth largest state in Nigeria. As demonstrated in Figure 2, Minna is situated at latitude $9^{\circ} 37^{\prime}$ North and longitude $6^{\circ} 33^{\prime}$ East. The northeast part of the city has a rock outcrop that acts as a physical constraint to development. Minna is 200 Kilometres from Abuja, the federal capital and covers 100,000 Hectares of land at the present development (Minna Master Plan, 1979). This increased the population of about 200,000 in 1991 to about 552,000 in 2017 (Sulyman et al., 2017). Minna as a city lies in North Central Nigeria, and it is in the Savannah region of the country. The average mean precipitation is $1,334 \mathrm{~mm}$ (52.52 inches) and the highest mean monthly rainfall is in September $(300 \mathrm{~mm}$ or 11.7 inches), and the mean monthly temperature is between 33 and $27^{\circ} \mathrm{C}$ (Nimet, 2010). Minna, in common with other cities in Nigeria experience both dry and rainy seasons. The dry season starts in October and lasts until April and has a strong north east trade wind known as the Harmattan wind or tornadoes. The wind is cool, dry, hazy and dusty. It brings about a cold environment with dryness. The rainy season starts at the end of April and lasts until mid-October and has a south west trade wind which brings about a warm, heavy wind that brings on the rain. 
The study was conducted among the patients of general hospital Minna, Niger state in Nigeria. The collection of field data for this study was carried out in four selected wards of the general hospital. The questionnaire survey was conducted in four wards, namely the amenity ward, surgical ward, pediatric ward and emergency ward. The studied wards were located in different parts of the hospital (Fig. 3).

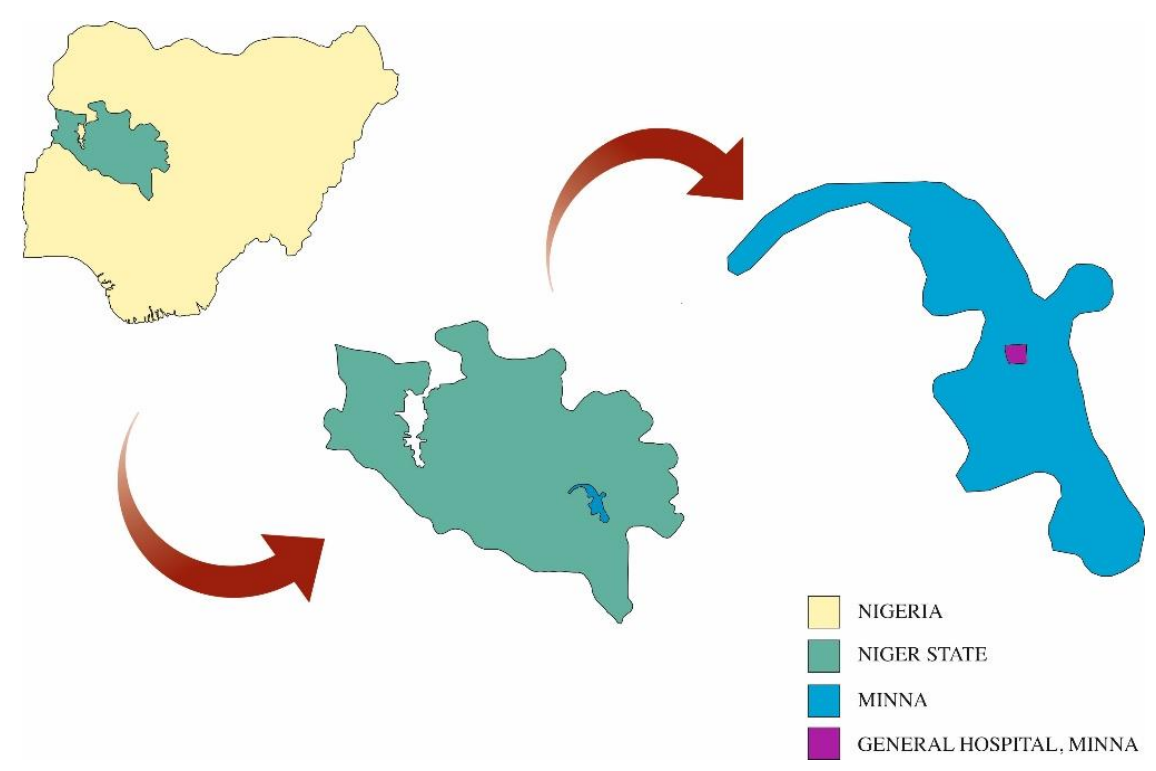

Figure 2. Showing the map of Minna, Niger State, Nigeria



Figure 3. Existing site layout of general hospital Minna

\section{Objective and subjective data collection}

Parameters such as temperature, relative humidity, illuminance, sound and $\mathrm{CO}_{2}$ were recorded within each ward throughout the day using DrDAQ (USB) CO122/133 and REED SD - 9901. DrDAQ (USB) CO122/133 was used to measure temperature, 
illuminance level and sound intensity level (Temperature range $0-70{ }^{\circ} \mathrm{C}$, accuracy $\pm 0.3{ }^{\circ} \mathrm{C}$, Light Intensity range $0-100$ and sound level range 55-100dBA, accuracy $\pm 5 \mathrm{dBA}$ ) while REED SD - 9901 was used to measure relative humidity and carbon dioxide concentration (Relative Humidity range $5-95 \%$, accuracy $\pm 3 \%$, Carbon dioxide range $0-4000 \mathrm{ppm}$, accuracy). The data loggers were placed on a table in the middle of the ward $1 \mathrm{~m}$ above the floor.

Questions related to each of the dimensions of the indoor environment (architectural design features, thermal, adaptive opportunity, lighting, acoustic and IAQ) were included in terms of adequacy, satisfaction, conduciveness and importance. A sevenpoint Likert-type scale was used to measure adequacy, satisfaction, conduciveness and importance. 300 questionnaires were distributed in four different wards on different days, during the period from February 2018 to April 2018. Out of 300 questionnaires distributed, only 280 were returned. Nine of the questionnaires were not used due to being incomplete. Therefore, a total of 271 questionnaires were used for the analysis.

\section{Data analysis}

Evaluating indoor conditions by means of surveys alongside measuring campaigns is a widely used approach that has been extensively tested (De Giuli et al., 2013; Sattayakorn et al., 2017; Verheyen et al., 2011). The objective data was collected using the above instruments and were compared to the recommended standards. The analysis of the patients' responses was carried out using SPSS version 23.0 and SmartPLS 3.0 version, frequently used for structural equation modelling (SEM) to test the fitness, estimate flexibility, and predicting both observed and latent variable influences on each other in a particular model.

\section{Results and analysis of the objective data}

The scientific measurement of the various climatic factors which affects the IEQ in the hospital ward was carried out using the identified instruments as shown in Table 1. These factors are temperature, relative humidity, sound, lighting and $\mathrm{CO}_{2}$. The temporal resolution of the measurements from this study has been displayed in the Appendix. However, the measurement for illumination and light intensity in the various wards surveyed was pegged at between $6 \mathrm{am}$ and $8 \mathrm{pm}$. This is so based on the noticeable challenge of power inefficiency in the study area. Nigeria has a serious energy supply deficit and this often applied to all class of infrastructure in the country (Olatunji et al., 2018). On the basis of this argument, the readings and measurements taken in the study area between $6 \mathrm{am}$ and $8 \mathrm{pm}$ is an aggregate of analysis between both natural and artificial lightning system, however beyond 8:00pm, lightening is basically dependent on artificial lightning which made reading difficult to examine because of the dearth in power supply, hence, the research considered lightening measure at periods when natural lighting can be relied upon in $d$ absence of the artificial lightning. The outcomes of these measurements are included in Table 2, which presents the various averages shown on the table for temperature, relative humidity, sound, lighting and $\mathrm{CO}_{2}$. The analysis shows that the average daily temperature for the various hospital wards examined were $33.8{ }^{\circ} \mathrm{C}$ for the surgical ward, $31.5^{\circ} \mathrm{C}$ for the emergency ward, $34.1^{\circ} \mathrm{C}$ in the amenity ward and $32.3{ }^{\circ} \mathrm{C}$ in the paediatric ward. The recommended standard of temperature ranges is between $23-26{ }^{\circ} \mathrm{C}$ (ASHRAE, 2006) and $24-33{ }^{\circ} \mathrm{C}$ (British Standards Institution, 2007). 
Table 1. IEQ mobile measurement station logger. (Source: Author's analysis, 2018)

\begin{tabular}{c|c|c|c|c}
\hline IEQ element & Instrument model & Resolution & Range & Accuracy \\
\hline Air temperature & Mastech MS8209 & $0.1{ }^{\circ} \mathrm{C} @ 25^{\circ} \mathrm{C}$ & $0-70{ }^{\circ} \mathrm{C}$ & $\pm 0.3{ }^{\circ} \mathrm{C}$ \\
\hline Relative humidity & Mastech MS8209 & $0.10 \%$ & $5-95 \%$ & $\pm 3 \%$ \\
\hline Light intensity & $\begin{array}{c}\text { DrDAQ (USB) } \\
\text { CO122/133 }\end{array}$ & 0.1 & $0-100$ & Manually calibrated \\
\hline Sound level & $\begin{array}{c}\text { DrDAQ (USB) } \\
\text { CO122/133 }\end{array}$ & $1 \mathrm{dBA}$ & $55-100 \mathrm{dBA}$ & $\pm 5 \mathrm{dBA}$ \\
\hline Carbon dioxide $\left(\mathrm{CO}_{2}\right)$ & REED SD -9901 & $1 \mathrm{ppm}$ & $0-4000 \mathrm{ppm}$ & $\pm 5 \%(>1000 \mathrm{ppm})$ \\
\hline
\end{tabular}

Table 2. Objectives measurements averages

\begin{tabular}{c|c|c|c|c|c|c}
\hline Month & Wards & Temp $\left({ }^{\circ} \mathrm{C}\right)$ & $\mathbf{R H}(\%)$ & Sound (dBA) & Lighting (lux) & $\mathbf{C O}_{2}$ (ppm) \\
\hline \multirow{4}{*}{ February } & Surgical & 33.8 & 55.5 & 43.5 & 371 & 510 \\
& Emergency & 31.5 & 55.0 & 44.9 & 402 & 496 \\
& Amenity & 34.1 & 54.9 & 46.1 & 410 & 495 \\
& Pediatric & 32.3 & 54.6 & 46.2 & 420 & 517 \\
\hline \multirow{5}{*}{ March } & Surgical & 33.8 & 54.5 & 43.8 & 403 & 490 \\
& Emergency & 33.6 & 54.9 & 45.1 & 397 & 498 \\
& Amenity & 33.9 & 55.2 & 45.7 & 399 & 487 \\
& Pediatric & 33.4 & 54.5 & 45.0 & 391 & 506 \\
\hline \multirow{5}{*}{ April } & Surgical & 34.1 & 54.1 & 43.8 & 402 & 497 \\
& Emergency & 34.0 & 54.8 & 45.0 & 402 & 493 \\
& Amenity & 33.0 & 54.6 & 46.0 & 403 & 506 \\
& Pediatric & 32.6 & 54.7 & 45.2 & 412 & 490 \\
\hline
\end{tabular}

Temp = temperature; $\mathrm{RH}=$ relative humidity

Furthermore, the average daily minimum and maximum temperatures range from $23.1^{\circ} \mathrm{C}$ and $33.4^{\circ} \mathrm{C}$ within the various wards examined between February, March and April. It was observed that the weather condition of the city and the internal environment of the hospital wards examined differ considerably given the temperature recorded within the chosen month. This suggests that such wards will require an external input in terms of artificial ventilation to help make the internal environment of the hospital wards conducive for patients who are treated for various medical conditions.

Another indoor element examined in the measurement is the relative humidity of the hospital wards. The analysis shows that the average daily relative humidity of the hospital wards within February, March and April ranges from an average daily range from 41.2 to $68.2 \%$ daily within the months sampled. The average relative humidity of the wards measured is presented as $55.5 \%$ for the surgical ward, $55.0 \%$ for the emergency ward, $54.9 \%$ in the amenity ward and $54.6 \%$ in the pediatric ward. However the recommended guideline for relative humidity by ASHRAE (2004a) is 30-60\%. Based on the data presented, relative humidity in the selected wards is within the recommended standard.

The sound level and acoustic properties of the hospital wards were also measured in the for the four wards sampled for this research. The measurement shows that the surgical ward has a daily average sound decibel of $43.5 \mathrm{dBA}$, the emergency ward is 
$44.9 \mathrm{dBA}$, the amenity ward is $46.1 \mathrm{dBA}$, and the paediatric ward is $46.2 \mathrm{dBA}$. This shows that most of the hospital wards are relatively noisy and unconducive for the patients. The daily sound level of the wards was measured at $26.6 \mathrm{dBA}$ minimum and 69.7 dBA maximum. However, the recommended sound level should not exceed $40 \mathrm{dBA}$ (WHO, 1999) and $60 \mathrm{dBA}$ (ASHRAE, 2007). From the sound measurement carried out, it shows that the highest level of noise is recorded in the afternoons of February across the hospital wards. This situation shows a serious challenge for design as most of the wards are expected to be designed in such a way that these high noise levels are properly managed in order to achieve a good level of comfort for the patients.

The lighting conditions of the wards were also examined between February-April. The analysis shows that the surgical ward has a daily average light intensity of 371 lux, the emergency ward is 402 lux, Amenity ward is 410 lux, and the paediatric ward is 420 lux. However, the recommended guideline is 100-225 lux (CIBSE, 1989). This shows that most of the hospital wards are bright during the day time and are above the recommended standard.

The particulate matter is another element of the indoor air quality that was measured in this research. The measurement of the particulate matter shows a daily minimum of $258 \mathrm{ppm}$ and $750 \mathrm{ppm}$. The measurement further showed that the surgical ward has a daily average $\mathrm{CO}_{2}$ of $510 \mathrm{ppm}$, the emergency ward is $496 \mathrm{ppm}$, amenity ward is $495 \mathrm{ppm}$, and the paediatric ward is $517 \mathrm{ppm}$. This measurement given the daily measures shows that the level of $\mathrm{CO}_{2}$ is within the acceptable range recommended of > 700 ppm (ASHRAE, 2010; British Standards Institution, 2007)

\section{Structural equation model}

Structural Equation Modeling (SEM) approaches are a second-generation multivariate technique that has been widely employed for investigating or testing the research model of several studies (Fornell and Bookstein, 1982). Using SEM is similar to the employment of Multiple Regression Analysis (Ali et al., 2018). In addition, SEM is used to predict the influence of the independent variable on the dependent variable of a particular research model. A two-stage analysis was conducted under the structural equation model in this study, first the assessment of the measurement model and secondly evaluating the structural model (Anderson and Gerbing, 1982).

\section{Content validity}

The content validity of the survey questionnaire in this current study was investigated in two ways. First, the questionnaire items were adopted from studies which has been used and tested. Second, the draft of the survey questionnaire was reevaluated by some professionals in the field under the study to ensure content validity.

\section{Internal consistency}

The internal consistency of the constructs was tested using Cronbach's alpha $(\alpha)$. The general accepted reliability or internal consistency of the constructs should be greater or equal to 0.70 (Hair et al., 2010). As indicated in Table 3, the Cronbach alpha ranges from 0.75 to 0.972 indicating high internal consistency. The skewness and Kurtosis indices are also presented in Table 3, to assess the normality of the data. Lei and Lomax (2005) suggest less than an absolute value $|2.3|$ for both skewness and kurtosis indices to ensure adequate data normality. 
Alfa - Öztürk: Perceived indoor environmental quality of hospital wards and patients' outcomes: a study of a general hospital, Minna, Nigeria $-8245$

Table 3. Summary of exploration factor analysis (EFA) results

\begin{tabular}{|c|c|c|c|c|}
\hline Constructs & Item descriptions & $\begin{array}{c}\text { Factor } \\
\text { loadings }\end{array}$ & Kurtosis & Skewness \\
\hline Acoustics (A) & $\mathrm{AVE}=0.953 ., \mathrm{CR}=0.976$ and $\alpha=0.952$ & & & \\
\hline AI & Satisfaction with the noise level & 0.970 & 0.519 & $-1,346$ \\
\hline $\mathrm{A} 2$ & Satisfaction with noise privacy & 0.982 & 0.577 & $-1,380$ \\
\hline Adaptive opportunities (AO) & $\mathrm{AVE}=0.681 ., \mathrm{CR}=0.864$ and $\alpha=0.757$ & & & \\
\hline $\mathrm{AO} 1$ & $\begin{array}{c}\text { Satisfaction with the freedom to switch the ceiling fans } \\
\text { on/off }\end{array}$ & 0.692 & -0.576 & -0.925 \\
\hline $\mathrm{AO} 2$ & $\begin{array}{l}\text { Satisfaction with the freedom to open/close the window } \\
\text { shutters }\end{array}$ & 0.885 & -0.407 & -0.936 \\
\hline $\mathrm{AO} 3$ & $\begin{array}{l}\text { Satisfaction with the freedom to switch the fluorescent } \\
\text { lamps on/off }\end{array}$ & 0.884 & -0.082 & -0.996 \\
\hline Conducive ward (CW) & $\mathrm{AVE}=0.972 ., \mathrm{CR}=0.986$ and $\alpha=0.972$ & & & \\
\hline CW1 & How conducive is the ward for the wellbeing & 0.985 & -1.810 & -0.168 \\
\hline CW2 & How can you rate the level of conduciveness of the ward & 0.987 & -1.731 & -0.211 \\
\hline Architectural design features (ADF) & $\mathrm{AVE}=0.895 ., \mathrm{CR}=0.962$ and $\alpha=0.942$ & & & \\
\hline ADF1 & Adequacy of openings in the ward & 0.936 & -0.854 & -0.817 \\
\hline ADF2 & Satisfaction with ward layout & 0.955 & -0.660 & -0.855 \\
\hline ADF3 & Satisfaction with a hospital bed (furniture) & 0.948 & -0.604 & -0.888 \\
\hline Health recovery (HR) & $\mathrm{AVE}=0.926 ., \mathrm{CR}=0.962$ and $\alpha=0.921$ & & & \\
\hline HR1 & Satisfaction with Health Recovery rate & 0.967 & $-1,159$ & -0.257 \\
\hline HR2 & Satisfaction with Health Recovery & 0.958 & $-1,106$ & -0.251 \\
\hline Health satisfaction (HS) & $\mathrm{AVE}=0.923 ., \mathrm{CR}=0.960$ and $\alpha=0.916$ & & & \\
\hline HS1 & $\begin{array}{l}\text { How do you perceive the Overall health satisfaction } \\
\text { within the ward? }\end{array}$ & 0.961 & -0.854 & -0.817 \\
\hline HS2 & How do you rate the overall Health satisfaction & 0.960 & -0.660 & -0.855 \\
\hline Indoor air quality (IAQ) & $\mathrm{AVE}=0.943 ., \mathrm{CR}=0.971$ and $\alpha=0.940$ & & & \\
\hline IAQ1 & Satisfaction with air quality & 0.966 & 0.725 & $-1,388$ \\
\hline IAQ2 & Satisfaction with air exchange rate & 0.976 & 0.453 & $-1,389$ \\
\hline Lighting (L) & $\mathrm{AVE}=0.908 ., \mathrm{CR}=0.952$ and $\alpha=0.900$ & & & \\
\hline L1 & Satisfaction with the amount of daylight & 0.942 & -0.892 & -0.597 \\
\hline L2 & Satisfaction with visibility or with the amount of light & 0.964 & -0.787 & -0.722 \\
\hline \multirow[t]{3}{*}{$\begin{array}{l}\text { Perceived importance of indoor } \\
\text { environmental quality (PI-IEQ) }\end{array}$} & $\mathrm{AVE}=0.853 ., \mathrm{CR}=0.921$ and $\alpha=0.830$ & & & \\
\hline & How do you perceive the importance of IEQ & 0.941 & $-1,106$ & -0.251 \\
\hline & How do you rate the perceived importance of IEQ & 0.906 & -0.787 & -0.722 \\
\hline \multirow[t]{3}{*}{$\begin{array}{l}\text { Perceived indoor environmental } \\
\text { quality (PIEQ) }\end{array}$} & $\mathrm{AVE}=0.927 ., \mathrm{CR}=0.962$ and $\alpha=0.922$ & & & \\
\hline & Overall satisfaction with the Perceived IEQ of the ward & 0.965 & 0.483 & $-1,332$ \\
\hline & How do you rate the perceived IEQ of the ward & 0.961 & 0.802 & $-1,424$ \\
\hline Therapeutic ambience (TA) & $\mathrm{AVE}=0.769 ., \mathrm{CR}=0.869$ and $\alpha=0.705$ & & & \\
\hline TA1 & $\begin{array}{l}\text { How do you perceive Therapeutic ambience of the } \\
\text { hospital ward }\end{array}$ & 0.841 & 1,523 & $-1,161$ \\
\hline TA2 & $\begin{array}{l}\text { How do you perceive the Therapeutic ambience of the } \\
\text { hospital environment }\end{array}$ & 0.912 & 0.422 & -0.962 \\
\hline Thermal comfort (TC) & $\mathrm{AVE}=0.972 ., \mathrm{CR}=0.986$ and $\alpha=0.972$ & & & \\
\hline $\mathrm{TC} 1$ & Satisfaction with temperature & 0.985 & $-1,810$ & -0.168 \\
\hline TC2 & Satisfaction with relative humidity & 0.987 & $-1,731$ & -0.211 \\
\hline
\end{tabular}

\section{Convergent validity}

Average variance extracted (AVE) composite reliability (CR) and factor loadings were used to measure convergent validity. Each factor loading is expected to be above a 
0.70 threshold (Kurfali et al., 2017). All factors loadings were above 0.60. The recommended AVE values should be more than 0.5 while CR values exceed 0.7 for accepted convergent validity (Hair et al., 2010). As indicated in Table 3, AVE value ranges from 0.681 to 0.972 while $\mathrm{CR}$ value ranges from 0.869 to 0.986 , suggesting significant level of approval (Sarstedt et al., 2014).

\section{Discriminant validity}

The discriminant validity is said to be attained if the square root of the Average Variance Extracted (AVE) for individual constructs are higher than the inter-factor correlation between the construct in the model (Chin, 1998; Hair et al., 2010; Kurfali et al., 2017) as boldly shown in the diagonal cells in Table 4. The general results in Table 5 were within the endorsed values. The general results satisfy the discriminant validity recommendation of the model construct.

Table 4. Correlation matrix of the constructs

\begin{tabular}{c|c|c|c|c|c|c|c|c|c|c|c|c}
\hline & A & AD & CW & ADF & HR & HS & IAQ & L & PI-IEQ & PIEQ & TA & TC \\
\hline A & $\mathbf{0 . 9 7 6}$ & & & & & & & & & & & \\
AD & 0.255 & $\mathbf{0 . 8 2 5}$ & & & & & & & & & & \\
CW & 0.137 & 0.300 & $\mathbf{0 . 9 8 6}$ & & & & & & & & & \\
ADF & 0.260 & 0.609 & 0.341 & $\mathbf{0 . 9 4 6}$ & & & & & & & & \\
HR & 0.185 & 0.049 & 0.254 & 0.215 & $\mathbf{0 . 9 6 2}$ & & & & & & & \\
ADF & 0.220 & 0.580 & 0.347 & 0.478 & 0.184 & $\mathbf{0 . 9 6 1}$ & & & & & & \\
IAQ & 0.096 & 0.094 & 0.047 & 0.119 & 0.059 & 0.124 & $\mathbf{0 . 9 7 1}$ & & & & & \\
L & 0.120 & 0.421 & 0.300 & 0.564 & 0.318 & 0.531 & 0.150 & $\mathbf{0 . 9 5 3}$ & & & & \\
PI-IEQ & 0.136 & 0.428 & 0.357 & 0.565 & 0.379 & 0.533 & 0.142 & 0.446 & $\mathbf{0 . 9 2 4}$ & & & \\
PIEQ & 0.331 & 0.661 & 0.528 & 0.642 & 0.215 & 0.628 & 0.298 & 0.486 & 0.557 & $\mathbf{0 . 9 6 3}$ & & \\
TA & 0.082 & 0.128 & 0.110 & 0.199 & 0.099 & 0.226 & 0.106 & 0.145 & 0.116 & 0.076 & $\mathbf{0 . 8 7 7}$ & \\
TC & 0.137 & 0.300 & 0.340 & 0.341 & 0.254 & 0.347 & 0.047 & 0.300 & 0.357 & 0.528 & 0.110 & $\mathbf{0 . 9 8 6}$ \\
\hline
\end{tabular}

Diagonal elements are square roots of AVE (in bold)

$\mathrm{A}=$ Acoustics, $\mathrm{AD}=$ Adaptive opportunity, $\mathrm{CW}=$ Conducive ward, $\mathrm{ADF}=$ Architectural design features, $\quad H R=$ Health recovery, $\quad I A Q=$ Indoor air quality, $L=$ Lightning, $\quad$ PI-IEQ $=$ Perceived importance of indoor environmental quality, $\mathrm{PIEQ}=$ Perceived indoor environmental quality, $\mathrm{TA}=$ Therapeutic Ambience, $\mathrm{TC}=$ Thermal comfort

\section{Evaluation of structural model and hypotheses}

Generally, the CFI, NFI values are expected to be 0.9 and RMSEA $\leq 0.08$ and SRMSR $\leq 0.05$ (Hooper et al., 2008; Wong et al., 2014) to indicate a good model fit. As indicated in Table 5, the statistical results shown Chi-square/degree of freedom $\left(\chi^{2} / \mathrm{df}\right)=2.804, \mathrm{CFI}=0.964, \mathrm{RMSEA}=0.0432, \mathrm{P}$-value $=0.002, \mathrm{NFI}=0.950$, and SRMSR $=0.0454$. This suggested that the model for this current study has a good fit.

As indicated in Table 6 and Figure 4, the result from the hypothesis H4, H12, H2, and $\mathrm{H} 7$ were all supported. That is Architectural design features $(\beta=0.263$, $\mathrm{p}=0.022>0.05)$, Thermal comfort $(\beta=0.304, \mathrm{p}=0.000<0.05)$, Adaptive opportunity $(\beta=0.268, p=0.010<0.005)$ and indoor air quality $(\beta=0.209, p=0.002<0.05)$ have a positive influence on the Perceived Indoor Environmental Quality of the studied hospital wards. However, H1 and H8 were not supported. Thus, Acoustics $(\beta=0.122$, 
$\mathrm{p}=0.109>0.05)$ and lighting $(\beta=0.087, \mathrm{p}=0.375>0.05)$ also have no significant effect on perceived indoor environmental quality. Furthermore, Hypotheses, H9 and H10 were supported. The Perceived Indoor Environmental Quality was positive and had a significant influence on the conducive ward $(\beta=0.502, p=0.000<0.05)$ and the perceived importance of indoor environmental quality $(\beta=0.268, p=0.048<0.05)$. Also, H3 was not supported. That is, the conducive ward $((\beta=0.048, p=0.600>0.05)$ has no significant influence on the perceived importance of indoor environmental quality.

Table 5. Confirmatory factor analysis

\begin{tabular}{|c|c|c|}
\hline Fit indices & Recommended value & Research model \\
\hline Chi square/degree of freedom ( $\left.\chi^{2} / \mathrm{df}\right)$ & $\leq 3.00$ & 2.804 \\
\hline P-value & $\leq 0.05$ & 0.002 \\
\hline Comparative fit index (CFI) & $\geq 0.90$ & 0.964 \\
\hline Normed fit index (NFI) & $\geq .90$ & 0.950 \\
\hline Standardized root mean square residual (SRMSR) & $\leq 0.05$ & 0.0454 \\
\hline Root mean square error of approximation (RMSEA) & $\leq 0.08$ & 0.0432 \\
\hline
\end{tabular}

In addition, Hypotheses $\mathrm{H} 5$ and $\mathrm{H} 6$ were supported. Indicating that, Health Recovery $(\beta=0.223, p=0.011<0.05)$ and Health Satisfaction $(\beta=0.264, p=0.015<0.05)$ has a positive influence on the perceived importance of the indoor environmental quality. However, Hypothesis, H11 was not supported. This suggests that Therapeutic Ambience $(\beta=0.025, p=0.761>0.005)$ has no significant influence on the perceived importance of indoor environmental quality. Lastly $59.4 \%, 34.9 \%$ and $25.2 \%$ of the variance in the perceived indoor environmental quality, perceived importance of indoor environmental quality and conducive ward are explained respectively as presented in Figure 4.

Table 6. Summarised structural modelling results

\begin{tabular}{c|c|c|c|c|c}
\hline & Hypotheses & Path coefficient & T statistics & P values & Decision \\
\hline H1 & A - > PIEQ & 0.122 & 1.605 & 0.109 & Not supported \\
H2 & AO - > PIEQ & 0.268 & 2.577 & $0.010^{* *}$ & Supported \\
H3 & CW - > PI-IEQ & 0.048 & 0.525 & 0.600 & Not supported \\
H4 & ADF - > PIEQ & 0.263 & 2.303 & $0.022^{* *}$ & Supported \\
H5 & HR - > PI-IEQ & 0.223 & 2.556 & $0.011^{* *}$ & Supported \\
H6 & HS - > PI-IEQ & 0.264 & 2.432 & $0.015 * *$ & Supported \\
H7 & IAQ - > PIEQ & 0.209 & 3.124 & $0.002 * *$ & Supported \\
H8 & L - > PIEQ & 0.087 & 0.889 & 0.375 & Not supported \\
H9 & PIEQ - > CW & 0.502 & 7.048 & $0.000^{* *}$ & Supported \\
H10 & PIEQ - > PI-IEQ & 0.268 & 1.981 & $0.048 * *$ & Supported \\
H11 & TA - > PI-IEQ & 0.025 & 0.305 & 0.761 & Not supported \\
H12 & TC - > PIEQ & 0.304 & 4.611 & $0.000^{* *}$ & Supported \\
\hline
\end{tabular}

Significant at $* * \mathrm{p}<0.05$ 


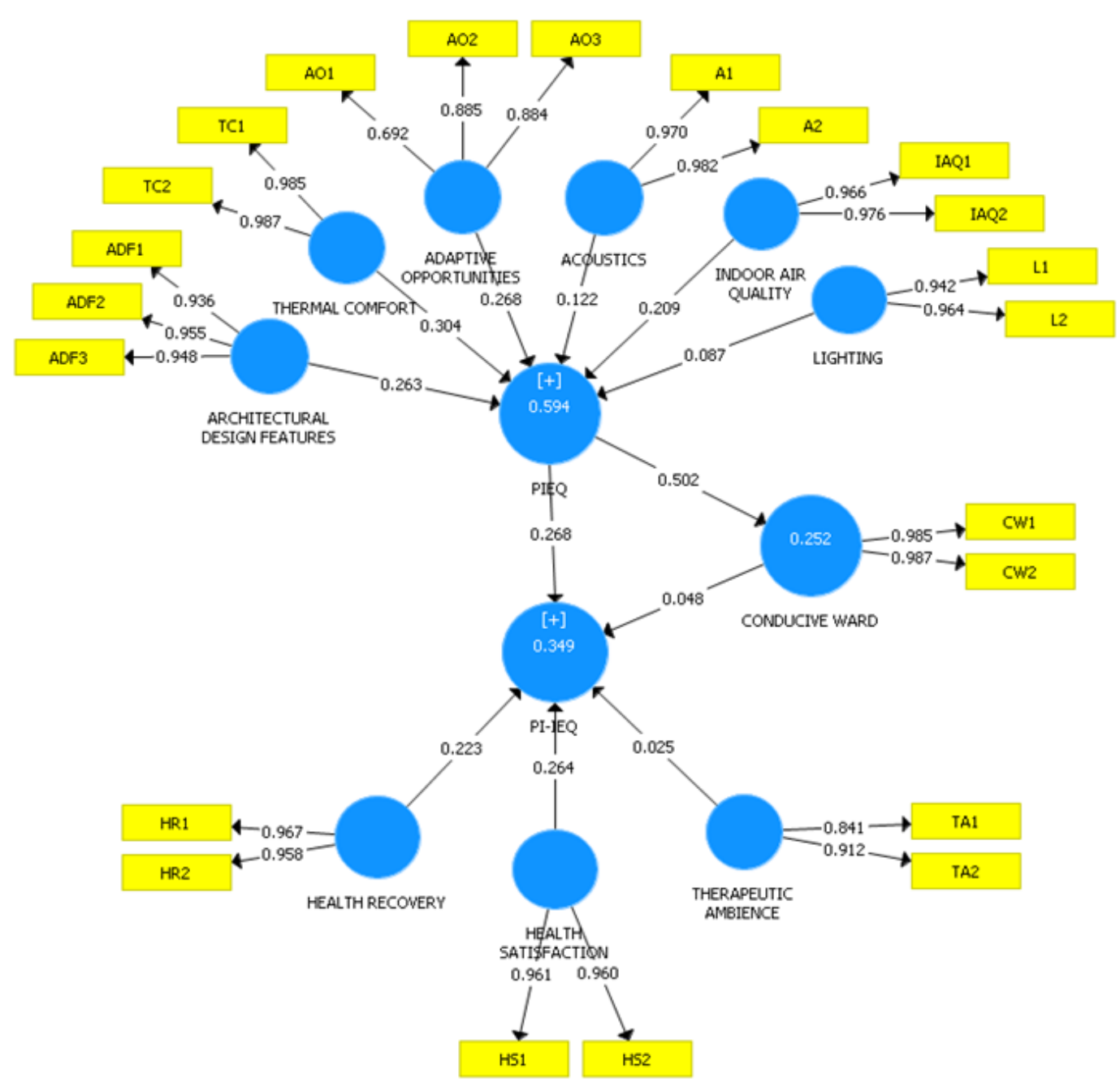

Figure 4. Structural model evaluation

\section{Discussion}

The six factors that influence PIEQ were consistent with the findings obtained from the literature review. Several types of research conducted indicate that patient's perception significantly relied on design features and ambient attributes (air quality, temperature, daylight, acoustics and artificial lighting) in hospital wards (Ghalib,2018; Gou et al., 2018; Iyendo et al., 2016; Salonen et al., 2013).

In this study, Adaptive opportunity in the context of IAQ and lighting includes the freedom to switch the ceiling fans, freedom to open/close the window shutter and freedom to switch fluorescent lamps. The provision of opportunities to control the patient's indoor environment improved the thermal and visual comfort and satisfaction with IAQ (Fisk, 2000). Occupants attempt to restore their thermal comfort by responding consciously or unconsciously to the thermal environment (Nicol and Humphreys, 2002) and by adjusting the personal environment conditions by opening/closing windows or switching fans on/off (de Dear and Brager, 1998).

Architectural design features were the third most influencing factor on PIEQ in this study (Fig. 5). Architectural design features in ward play an important role and health satisfaction of patients (Bosch and Lorusso, 2019; Devlin and Arneill, 2003; Douglas 
and Douglas, 2004). The beds in the studied wards are fixed and unable to be adjusted by the patients. A flexible bed that could be adjusted to the different comfort level of the patient contributes to the conducive space. The spaces between the beds are not sufficient for patients to move around and for staff to treat patients. The layout of the wards contributes to the health satisfaction of the patients depending on the arrangement of the beds in the ward (Bosch and Lorusso, 2019; Liu et al., 2018; Schweitzer et al., 2004). The number and size of opening influence the temperature, ambient air, and lighting in the ward which effect on the perception of the patients.

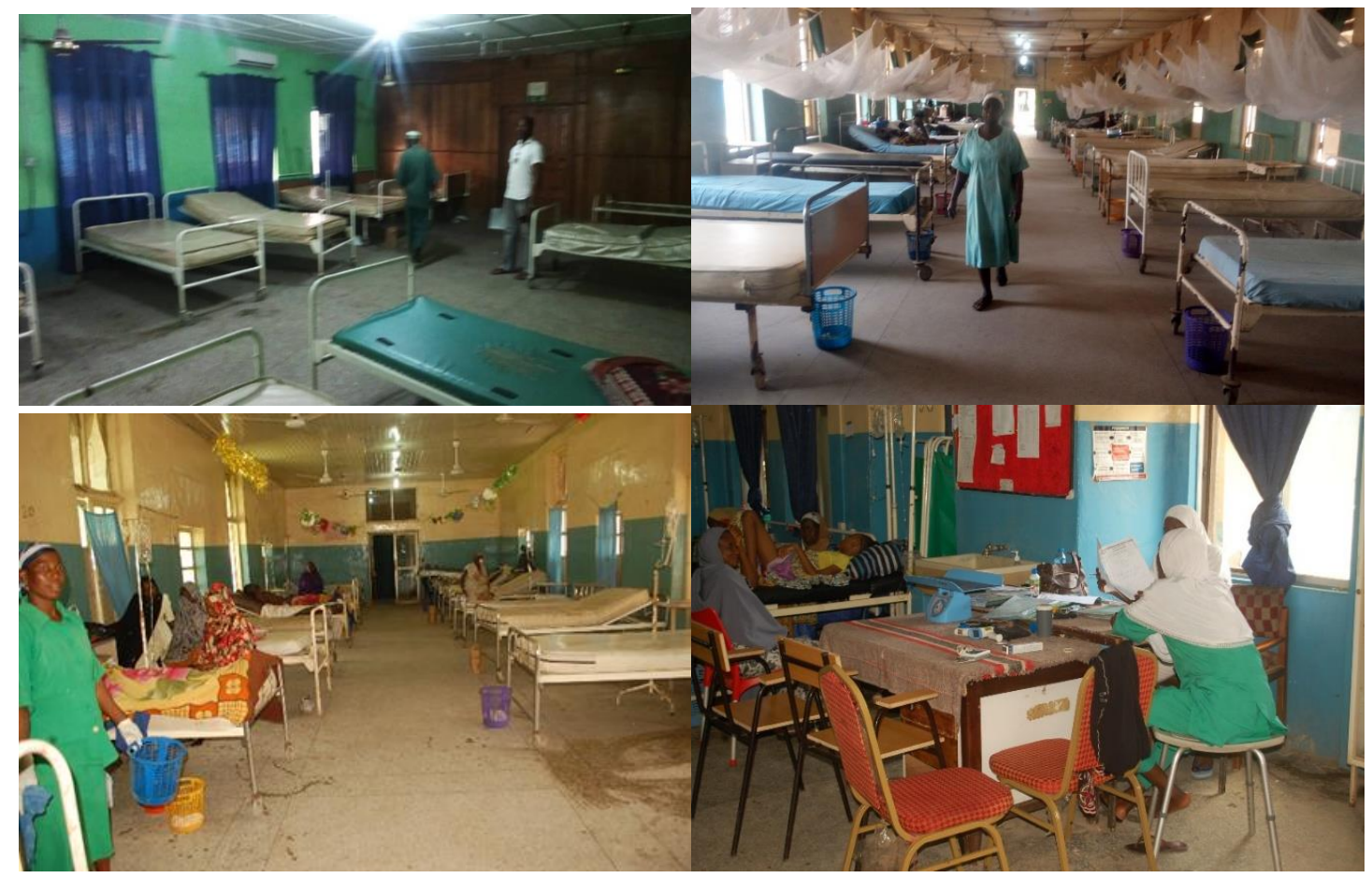

Figure 5. Interior views of the selected wards

In this study, visual comfort influence on patients in the wards is positive but not significant. Daylight levels in a ward depend upon the size of several windows, and their orientation and location within the building (Fig. 6). The orientation of the wards is the same, and also the acoustics of the wards was observed to have a positive influence on PIEQ which was not significant.

Interestingly, in this study, thermal conditions had the highest influence on PIEQ. As per Frontczak and Wargocki (2011), thermal comfort was accorded greater importance compared to visual and acoustic comfort and IAQ by the occupants, and it had a higher degree of influence on the overall satisfaction with IEQ compared to other indoor environmental factors. Studies have reported that temperature had the most influence on patients' perceptions of healing environments (De Giuli et al., 2013). All the selected wards in this study depend on the combination of cross-ventilation and the use of ceiling fans.

Conducive and comfortable wards that meet the needs of patients facilitate recovery and health satisfaction (Doyle et al., 2013; Hughes, 2008; Lim et al., 2019; Reiling et al., 2008). It was observed from this study that the higher the PIEQ, the higher the perception of the wards being perceived conducive. Rarely have researchers 
investigated the influence of health recovery, health satisfaction and therapeutic ambience on PI-IEQ. Interestingly, this study revealed that Health satisfaction had the most positive influence, followed by heath recovery. Moreover, therapeutic ambience had a positive influent but not significant.

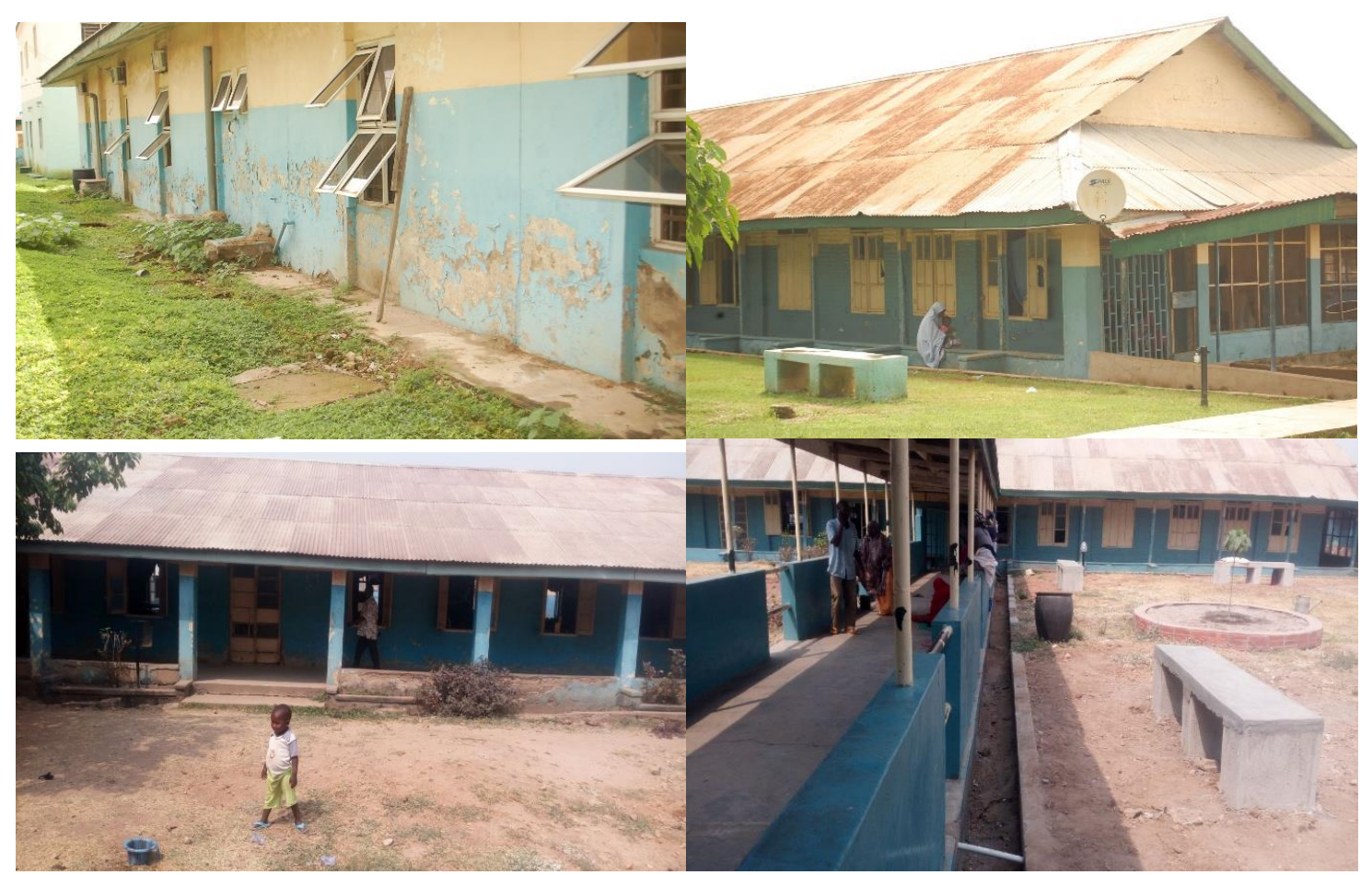

Figure 6. Exterior views of the selected wards

\section{Summary}

Comfortable thermal environment helps to maintain patients' mood and improves the healing of patients. From the objective survey, the high temperature levels increases toxins rate from building materials and also reduce the recovery rate of the patients in the wards (Kameel and Khalil, 2003). This may increase the lenght of stay of the patients in the wards. Sound level affects comfort and well-being of patients according to Cunha and Silva (2015). The level of noise in this current study can lead to increase in the use of drugs, cardiovascular disease, sleep disruption and hearing loss of the patients. A similar study conducted in Nigeria revealed that most of the indoor environmental quality factors were either above or below the recommended standards (Nimlyat and Kandar, 2015). Temperature and lighting were above the recommended standard in the previous study.

On the other hand, the subjective survey indicated that thermal comfort had the highest influence on the perceived indoor environmental quality in this study. This conforms to the findings of other studies conducted in the tropics (De Giuli et al., 2013; Sattayakorn et al., 2017). Most patients in this study were not satisfied with the adequacy of openings, layout and bed space which contributes to the indoor environment as also reported in a study by De Giuli et al. (2013). Architectural design features such as layout, bed space and openings had significant influence on the PIEQ, as architecture has a role to play in IEQ of buildings (Biancheri and Landi, 2017; 
Alfonsi et al., 2014; Mourshed and Zhao, 2012). Patients chose health satisfaction over health recovery and therapeutic ambience as factors influencing PI-IEQ. This implies that, health satisfaction is more important to the patient followed by the health recovery.

\section{Conclusions, implications and limitations}

In this study, objective physical measurements and a questionnaire based subjective survey were conducted to investigate the IEQ of four different wards in the General hospital at Minna, Nigeria. Objective measurements of IEQ include temperature, humidity, acoustics, air quality and illuminance. The measurement was recorded daily for three months. Two hundred and seventy-one (271) questionnaires were retrieved from the patients in different wards during the recording period.

From the Objective measurement, temperature, relative humidity, illuminance and sound level were all above recommended guidelines of WHO, British standards and ASHRAE. On the other hand, results from the subjective survey indicated that thermal comfort, adaptive opportunity, architectural features, air quality, lighting and acoustics positively affect the PIEQ. However, Acoustics and lighting do not have a significant influence on PIEQ in this study. An improved PIEQ of patients significantly increases the level of conduciveness of ward and also PI-IEQ of the ward. It was observed that health satisfaction health recovery and therapeutic ambience had a positive influence on PI-IEQ respectively.

Nigeria, being the most populous nation in Africa, has a large number of cases of widespread communicable diseases and an increasing population of more than 190 million. More than 30,000 Nigerians spend \$1 billion annually on medical tourism because of the state of health services (Nigeria Investment Promotion Commission, 2019). With a need for more hospitals and proposals to add more wards to the existing hospitals to meet the growing demand of healthcare services, focus need to be accorded by health practitioners and architects to the design of hospital wards. This study added to the existing knowledge of healing environments, in terms of the outcome of the patient's perception of the hospital ward, particularly through PIEQ and PI-IEQ.

The objective data analysis was limited, as data was collected within three months of the dry season. There will be a need for data collection throughout the year in order to understand the role of other influential factors that may affect PIEQ evaluation in hospital buildings in general. Architectural design features were only limited to layout, the opening of windows and furniture (bed). Other design features such as material finishes, landscape elements, bed spaces etc. should be studied in detail to ascertain how they influence the PIEQ.

Acknowledgements. The authors are grateful to Niger state ministry of health for the permission of using general hospital Minna as a case study.

\section{REFERENCES}

[1] Alfonsi, E., Capolongo, S., Buffoli, M. (2014): Evidence based design and healthcare - an unconventional approach to hospital design. - Ann Ig 26(2): 137-43.

[2] Ali, F., Rasoolimanesh, S. M., Sarstedt, M., Ringle, C. M., Ryu, K. (2018): An assessment of the use of partial least squares structural equation modeling (PLS-SEM) in 
hospitality research. - International Journal of Contemporary Hospitality Management 30(1): 514-538.

[3] Al-Rajhi, S., Ramaswamy, M., Al-Jahwari, F. (2010): IAQ in hospitals - better health through indoor air quality awareness. - Proceedings of the Tenth International Conference Enhanced Building Operations, Kuwait, October 26-28, 2010.

[4] Anam, S. I. (2018): Assessment of thermal comfort of non-airconditioned in-patient hospital wards in Dhaka during warm, humid periods. - Dissertation submitted in partial fulfillment of the requirements for the degree of master of architecture. Department of Architecture Bangladesh University of Engineering and Technology Dhaka, Bangladesh.

[5] Anderson, J. C., Gerbing, D. W. (1982): Some methods for respecifying measurement models to obtain unidimensional construct measurement. - Journal of Marketing Research 19(4): 453-460.

[6] ASHRAE (2004a): Standard 90.1-2004, Energy Standard for Buildings Except Low Rise Residential Buildings. - American Society of Heating, Refrigerating and AirConditioning Engineers, Inc, Atlanta, GA.

[7] ASHRAE (2004b): Thermal Environmental Conditions for Human Occupancy, Vol. 55. American Society of Heating, Refrigerating and Air-Conditioning Engineers, Atlanta, GA.

[8] ASHRAE (2006): Refrigeration. - American Society of Heating, Refrigerating and AirConditioning Engineers, Atlanta, GA.

[9] ASHRAE (2007): ASHRAE Applications Handbook. Atlanta, USA. - American Society of Heating, Refrigeration, and Air-conditioning Engineers, Inc, Atlanta, GA.

[10] ASHRAE (2010): ANSI/ASHRAE 62.1 - 2010. Atlanta, USA. - American Society of Heating, Refrigeration, and Air-conditioning Engineers, Inc, Atlanta, GA.

[11] Benedetti, F., Colombo, C., Barbini, B., Campori, E., Smeraldi, E. (2001): Morning sunlight reduces length of hospitalization in bipolar depression. - Journal of Affective Disorders 62(3): 221-223.

[12] Beute, F., de Kort, Y. A. (2014): Salutogenic effects of the environment: review of health protective effects of nature and daylight. - Applied Psychology, Health and Well-Being 6(1): 67-95.

[13] Biancheri, R., Landi, S. (2017): Gender and healthcare environments: a proposal of gender-sensitive methodology for improving the environmental quality in the existing heritage. Territorio della Ricerca su Insediamenti e Ambiente. - Rivista Internazionale di Cultura Urbanistica 17: 69-82.

[14] Bosch, S. J., Lorusso, L. N. (2019): Promoting patient and family engagement through healthcare facility design: a systematic literature review. - Journal of Environmental Psychology.

[15] Brager, G., Paliaga, G., De Dear, R. (2004): Operable windows, personal control and occupant comfort. - ASHRAE Transactions 110: 17-35.

[16] British Standards Institution (2007): BS EN 15251: Indoor Environmental Input Parameters for Design and Assessment of Energy Performance of Buildings Addressing Indoor Air Quality, Thermal Environment, Lighting and Acoustics. - British Standard Institution, London.

[17] Calama-González, C. M., León-Rodríguez, Á. L., Suárez, R. (2019): Daylighting performance of solar control films for hospital buildings in a Mediterranean climate. Energies 12(3): 489.

[18] CEN 15251 (2007): Indoor Environmental Input Parameters for Design and Assessment of Energy Performance of Buildings Addressing Indoor Air Quality, Thermal Environment, Lighting and Acoustics. - CEN, Brussels, Belgium.

[19] Chin, W. W. (1998): The partial least squares approach to structural equation modeling. Modern Methods for Business Research 295(2): 295-336. 
[20] Choi, J. H., Beltran, L. O., Kim, H. S. (2012): Impacts of indoor daylight environments on patient average length of stay (ALOS) in a healthcare facility. - Building and Environment 50: 65-75.

[21] CIBSE (1989): Lighting Guide: Hospitals and Healthcare Buildings. - CIBSE, London.

[22] Cunha, M., Silva, N. (2015): Hospital noise and patients' wellbeing. - Procedia-Social and Behavioral Sciences 171: 246-251.

[23] Dalke, H., Little, J., Niemann, E., Camgoz, N., Steadman, G., Hill, S., Stott, L. (2006): Colour and lighting in hospital design. - Optics \& Laser Technology 38(4-6): 343-365.

[24] de Dear, R. J., Akimoto, T., Arens, E. A., Brager, G., Candido, C., Cheong, K. W. D. Toftum, J. et al. (2013): Progress in thermal comfort research over the last twenty years. Indoor air 23(6): 442-461.

[25] de Dear, R., Brager, G. S. (1998): Developing an adaptive model of thermal comfort and preference. - ASHRAE Transactions 104(1): 145-167.

[26] De Giuli, V., Zecchin, R., Salmaso, L., Corain, L., De Carli, M. (2013): Measured and perceived indoor environmental quality: Padua Hospital case study. - Building and Environment 59: 211-226.

[27] Devlin, A. S., Arneill, A. B. (2003): Health care environments and patient outcomes: A review of the literature. - Environment and Behavior 35(5): 665-694.

[28] Djongyang, N., Tchinda, R., Njomo, D. (2010): Thermal comfort: A review paper. Renewable and Sustainable Energy Reviews 14(9): 2626-2640.

[29] Douglas, C. H., Douglas, M. R. (2004): Patient-friendly hospital environments: exploring the patients' perspective. - Health Expectations 7(1): 61-73.

[30] Doyle, C., Lennox, L., Bell, D. (2013): A systematic review of evidence on the links between patient experience and clinical safety and effectiveness. - BMJ Open 3(1): $\mathrm{e} 001570$.

[31] Eames, I., Tang, J. W., Li, Y., Wilson, P. (2009): Airborne transmission of disease in hospitals. - Journal of the Royal Society Interface. DOI: 10.1098/rsif.2009.0407.focus.

[32] Elmenhorst, E. M., Pennig, S., Rolny, V., Quehl, J., Mueller, U., Maaß, H., Basner, M. (2012): Examining nocturnal railway noise and aircraft noise in the field: Sleep, psychomotor performance, and annoyance. - Science of the Total Environment 424: 4856.

[33] Erdogan, M. S., Yurtseven, E., Erginöz, E., Vehid, S., Köksal, S., Yüceokur, A. A. (2010): Total volatile organic compounds (TVOC), carbon monoxide (CO), carbon dioxide (CO2) concentrations in the hospital building of a medical faculty in Istanbul, Turkey. - Emergency 20: 23.

[34] European Standard (2008): UNE-EN 15251:2008. Indoor environmental input parameters for design and assessment of energy performance of buildings addressing indoor air quality, thermal environment, lighting and acoustics. - Aenor 1-52. https://doi.org/10.1520/E2019-03R13.Copyright.

[35] Fanger, P. O. (1970): Thermal comfort. Analysis and applications in environmental engineering. - Thermal comfort. Analysis and applications in environmental engineering.

[36] Fisk, W. J. (2000): Health and productivity gains from better indoor environments and their relationship with building energy efficiency. - Annual Review of Energy and the Environment 25(1): 537-566.

[37] Fornell, C., Bookstein, F. L. (1982): Two structural equation models: LISREL and PLS applied to consumer exit-voice theory. - Journal of Marketing Research 19(4): 440-452.

[38] Frontczak, M., Wargocki, P. (2011): Literature survey on how different factors influence human comfort in indoor environments. - Building and Environment 46(4): 922-937.

[39] Frumkin, H., Louv, R. (2007): The powerful link between conserving land and preserving health. - Land Trust Alliance Special Anniversary Report 2007: 1-5.

[40] Gardner, G., Collins, C., Osborne, S., Henderson, A., Eastwood, M. (2009): Creating a therapeutic environment: a non-randomised controlled trial of a quiet time intervention for patients in acute care. - International Journal of Nursing Studies 46(6): 778-786. 
[41] Ghalib, A. (2018): Enhancing Inclusive Design in Emergency Department Waiting Areas: A Mixed Methods Architectural Study of Five Toronto Hospitals. http://openresearch.ocadu.ca/id/eprint/2409.

[42] Gou, Z., Lau, S. S. Y., Chen, F. (2012): Subjective and objective evaluation of the thermal environment in a three-star green office building in China. - Indoor and Built Environment 21(3): 412-422.

[43] Gou, Z., Gamage, W., Lau, S., Lau, S. (2018): An investigation of thermal comfort and adaptive behaviors in naturally ventilated residential buildings in tropical climates: a pilot study. - Buildings 8(1): 5 .

[44] Hair, J. F., Black, W. C., Babin, B. J., Anderson, R. E. (2010): Multivariate data analysis (7th Ed.). - Prentice Hall, Upper Saddle River, NJ.

[45] Helton, W. S., Matthews, G., Warm, J. S. (2009): Stress state mediation between environmental variables and performance: the case of noise and vigilance. - Acta Psychologica 130(3): 204-213.

[46] Hofhuis, J. G., Langevoort, G., Rommes, J. H., Spronk, P. E. (2012): Sleep disturbances and sedation practices in the intensive care unit - a postal survey in the Netherlands. Intensive and Critical Care Nursing 28(3): 141-149.

[47] Hooper, D., Coughlan, J., Mullen, M. (2008): Structural equation modelling: guidelines for determining model fit. - Electronic Journal on Business Research Methods 6(1): 5360 .

[48] Hughes, R. G. (2008): Tools and strategies for quality improvement and patient safety. In Patient safety and quality: an evidence-based handbook for nurses. - Agency for Healthcare Research and Quality, Rockville, Maryland.

[49] Huisman, E. R., Morales, E., van Hoof, J., Kort, H. S. M. (2012): Healing environment: a review of the impact of physical environmental factors on users. - Building and Environment 58: 70-80.

[50] ISO 7730 (2005): Ergonomics of the thermal environment-analytical determination and interpretation of thermal comfort using calculation of the PMV and PPD indices and local thermal comfort criteria. - Management 3: 605-615. https://www.sis.se/api/document/preview/907006/.

[51] Iyendo, T. O., Uwajeh, P. C., Ikenna, E. S. (2016): The therapeutic impacts of environmental design interventions on wellness in clinical settings: a narrative review. Complementary Therapies in Clinical Practice 24: 174-188.

[52] John, G., Clements-Croome, D., Howe, J. (2010): A conceptual approach to determine optimal indoor air quality: a mixture experiment method. - Proceeding of the CLIMA Conference, Held in Antalya, Turkey, 9-12 May, 2010, pp. 193-203.

[53] Joseph, A. (2006): The Impact of the Environment on Infections in Healthcare Facilities. - Center for Health Design, Concord, CA.

[54] Joseph, A., Ulrich, R. (2007): Sound Control for Improved Outcomes in Healthcare Settings. - Center for Health Design, Concord, CA.

[55] Jung, C. C., Wu, P. C., Tseng, C. H., Su, H. J. (2015): Indoor air quality varies with ventilation types and working areas in hospitals. - Building and Environment 85: 190195.

[56] Kamalha, E., Zeng, Y., Mwasiagi, J. I., Kyatuheire, S. (2013): The comfort dimension; a review of perception in clothing. - Journal of Sensory Studies 28(6): 423-444.

[57] Kameel, R., Khalil, E. E. (2003): Energy efficiency, air quality, and comfort in airconditioned spaces. - ASME 2003 International Design Engineering Technical Conferences and Computers and Information in Engineering Conference (pp. 775-782). American Society of Mechanical Engineers.

[58] Kembel, S. W., Meadow, J. F., O’Connor, T. K., Mhuireach, G., Northcutt, D., Kline, J. et al. (2014): Architectural design drives the biogeography of indoor bacterial communities. - PloS One 9(1): e87093. 
[59] Khalid, W., Zaki, S. A., Rijal, H. B., Yakub, F. (2019): Investigation of comfort temperature and thermal adaptation for patients and visitors in Malaysian hospitals. Energy and Buildings 183: 484-499.

[60] Khodakarami, J., Nasrollahi, N. (2012): Thermal comfort in hospitals-A literature review. - Renewable and Sustainable Energy Reviews 16(6): 4071-4077.

[61] Kim, J., Zhou, Y., Schiavon, S., Raftery, P., Brager, G. (2018): Personal comfort models: predicting individuals' thermal preference using occupant heating and cooling behavior and machine learning. - Building and Environment 129: 96-106.

[62] Kurfali, M., Arifoglu, A., Tokdemir, G., Pacin, Y. (2017): Adoption of e-Government services in Turkey. - Computers in Human Behavior 66: 168-178.

[63] Lei, M., Lomax, R. G. (2005): The effect of varying degrees of nonnormality in structural equation modeling. - Structural Equation Modeling 12(1): 1-27.

[64] Leung, M., Chan, A. H. (2006): Control and management of hospital indoor air quality. Medical Science Monitor 12(3): SR17-SR23.

[65] Lim, E., Wynaden, D., Heslop, K. (2019): Changing practice using recovery-focused care in acute mental health settings to reduce aggression: A qualitative study. - International Journal of Mental Health Nursing 28(1): 237-246.

[66] Liu, Y., Wang, Z., Zhang, Z., Hong, J., Lin, B. (2018): Investigation on the indoor environment quality of health care facilities in China. - Building and Environment. DOI: 10.1016/j.buildenv.2018.05.054.

[67] Mackrill, J., Jennings, P., Cain, R. (2014): Exploring positive hospital ward soundscape interventions. - Applied Ergonomics 45(6): 1454-1460.

[68] Mahbob, N. S., Kamaruzzaman, S. N., Salleh, N., Sulaiman, R. (2011): A correlation studies of indoor environmental quality (IEQ) towards productive workplace. - 2nd International Conference on Environmental Science and Technology IPCBEE, Vol. 6. IACSIT Press, Singapore.

[69] Minna Master Plan (1979): The Capital City of Niger State. Town Planning Division, Ministry of Housing and Environment, Niger State. - Final Report. Prepared by Max Lock Group, Nig. Ltd. https://wedc-knowledge.lboro.ac.uk/details.html?id = 8324 .

[70] Monsén, M. G., Edéll-Gustafsson, U. M. (2005): Noise and sleep disturbance factors before and after implementation of a behavioural modification programme. - Intensive and Critical Care Nursing 21(4): 208-219.

[71] Mourshed, M., Zhao, Y. (2012): Healthcare providers' perception of design factors related to physical environments in hospitals. - Journal of Environmental Psychology 32(4): 362-370.

[72] Nicol, J. F., Humphreys, M. A. (1973): Thermal comfort as part of a self-regulating system. - Building Research \& Practice 1(3): 174-179.

[73] Nicol, J. F., Humphreys, M. A. (2002): Adaptive thermal comfort and sustainable thermal standards for buildings. - Energy and Buildings 34(6): 563-572.

[74] Nicol, F., Humphreys, M., Roaf, S. (2012): Adaptive Thermal Comfort: Principles and Practice. - Routledge, Abingdon.

[75] Nigeria Investment Promotion Commission (2019): https://www.nipc.gov.ng/overviewhealthcare. - Accessed on $15^{\text {th }}$ January, 2019.

[76] Nigeria Meteorological Agency (2010): Nigeria Climate Review Bulletin. http://www.nimetng.org/uploads/publication/2010\%20Climate\%20Review.pdf. Accessed on 19th March 2019.

[77] Nimlyat, P. S., Kandar, M. Z. (2015): Appraisal of indoor environmental quality (IEQ) in healthcare facilities: A literature review. - Sustainable Cities and Society 17: 61-68.

[78] Norbäck, D., Nordström, K. (2008): Sick building syndrome in relation to air exchange rate, $\mathrm{CO} 2$, room temperature and relative air humidity in university computer classrooms: an experimental study. - International Archives of Occupational and Environmental Health 82(1): 21-30. 
[79] Olatunji, O., Akinlabi, S., Oluseyi, A., Abioye, A., Ishola, F., Peter, M., Madushele, N. (2018): Electric power crisis in nigeria: a strategic call for change of focus to renewable sources. - IOP Conference Series: Materials Science and Engineering 413(1): 012053.

[80] Paevere, P., Brown, S., Leaman, A., Luther, M., Adams, R. (2008): Indoor environment quality and occupant productivity in the $\mathrm{CH} 2$ building. - SB08: Proceedings of the 2008 International Scientific Committee World Sustainable Building Conference (pp. 222229).

[81] Pati, D., Nanda, U. (2011): Influence of positive distractions on children in two clinic waiting areas. - HERD: Health Environments Research \& Design Journal 4(3): 124-140.

[82] Pérez-Padilla, R., Schilmann, A., Riojas-Rodriguez, H. (2010): Respiratory health effects of indoor air pollution. - The International Journal of Tuberculosis and Lung Disease 14(9): 1079-1086.

[83] Raanaas, R. K., Patil, G. G., Hartig, T. (2012): Health benefits of a view of nature through the window: a quasi-experimental study of patients in a residential rehabilitation center. - Clinical Rehabilitation 26(1): 21-32.

[84] Reiling, J., Hughes, R. G., Murphy, M. R. (2008): The impact of facility design on patient safety. In Patient safety and quality: An evidence-based handbook for nurses. - Agency for Healthcare Research and Quality (US).

[85] Ryherdet, E., West, J. E., Busch-Vishniac, I., Waye, K. P. (2008): Evaluating the hospital soundscape. - Acoust. Today 4(4): 22-29.

[86] Sadek, A. H., Nofal, E. M. (2013): Effects of indoor environmental quality on occupant satisfaction in healing environments. - Proceedings of the 1st Conference of the Egyptian Affiliation of International Building Performance Simulation Association, Towards Sustainable and Green Life, June, 2013, Cairo, Egypt.

[87] Sadrizadeh, S., Stensson, S., Marashian, S., Walker, I., Holmberg, S. (2018): Airborne bacteria inactivation in a hospital ward by ultraviolet irradiation. - The 4th International Conference on building Energy \& Environment (COBEE 2018). February 5-9 2018; Melbourne, Australia.

[88] Salonen, H., Lahtinen, M., Lappalainen, S., Nevala, N., Knibbs, L. D., Morawska, L., Reijula, K. (2013): Design approaches for promoting beneficial indoor environments in healthcare facilities: a review. - Intelligent Buildings International 5(1): 26-50.

[89] Sarstedt, M., Ringle, C. M., Hair, J. F. (2014): PLS-SEM: looking back and moving forward. - Long Range Planning 47(3): 132-137. https://doi.org/10.1016/j.lrp.2014.02.008.

[90] Sattayakorn, S., Ichinose, M., Sasaki, R. (2017): Clarifying thermal comfort of healthcare occupants in tropical region: a case of indoor environment in Thai hospitals. - Energy and Buildings 149: 45-57.

[91] Scholz, R., Hönning, A., Seifert, J., Spranger, N., Stengel, D. (2019): Effectiveness of architectural separation of septic and aseptic operating theatres for improving process quality and patient outcomes: a systematic review. - Systematic Reviews 8(1): 16.

[92] Schweitzer, M., Gilpin, L., Frampton, S. (2004): Healing spaces: elements of environmental design that make an impact on health. - Journal of Alternative \& Complementary Medicine 10(Supplement 1): S-71.

[93] Shepley, M. M. (2006): The role of positive distraction in neonatal intensive care unit settings. - Journal of Perinatology 26(S3): S34.

[94] Shi, Z., Qian, H., Zheng, X., Lv, Z., Li, Y., Liu, L., Nielsen, P. V. (2018): Seasonal variation of window opening behaviors in two naturally ventilated hospital wards. Building and Environment 130: 85-93.

[95] Short, A. E., Short, K. T., Holdgate, A., Ahern, N., Morris, J. (2011): Noise levels in an Australian emergency department. - Australasian Emergency Nursing Journal 14(1): 2631.

[96] Shrivastava, S. R., Shrivastava, P. S., Ramasamy, J. (2013): Airborne infection control in healthcare settings. - Infection Ecology \& Epidemiology 3(1): 21411. 
[97] Smith, A., Pitt, M. (2011): Sustainable workplaces and building user comfort and satisfaction. - Journal of Corporate Real Estate 13(3): 144-156.

[98] Sulyman, A. O., Abd'razack, N. T. A., Medayese, S. O. (2017): Ecological footprint of housing in Minna, Nigeria. - Journal of Applied Sciences \& Environmental Sustainability 3(7): 68-84.

[99] Toftum, J. (2010): Central automatic control or distributed occupant control for better indoor environment quality in the future. - Building and Environment 45(1): 23-28.

[100] Ulrich, R. S. (1991): Effects of interior design on wellness: Theory and recent scientific research. - Journal of Health Care Interior Design 3(1): 97-109.

[101] Ulrich, R. S., Zimring, C., Zhu, X., DuBose, J., Seo, H. B., Choi, Y. S. et al. (2008): A review of the research literature on evidence-based healthcare design. - HERD: Health Environments Research \& Design Journal 1(3): 61-125.

[102] USEPA (US Environmental Protection Agency) (2015): Connectivity of streams and wetlands to downstream waters: a review and synthesis of the scientific evidence. USEPA, Washington, DC.

[103] Verde, S. C., Almeida, S. M., Matos, J., Guerreiro, D., Meneses, M., Faria, T. et al. (2015): Microbiological assessment of indoor air quality at different hospital sites. Research in Microbiology 166(7): 557-563.

[104] Verheyen, J., Theys, N., Allonsius, L., Descamps, F. (2011): Thermal comfort of patients: Objective and subjective measurements in patient rooms of a Belgian healthcare facility. - Building and Environment 46(5): 1195-1204.

[105] Wan, G. H., Chung, F. F., Tang, C. S. (2011): Long-term surveillance of air quality in medical center operating rooms. - American Journal of Infection Control 39(4): 302-308.

[106] Waye, K. P., Elmenhorst, E. M., Croy, I., Pedersen, E. (2013): Improvement of intensive care unit sound environment and analyses of consequences on sleep: an experimental study. - Sleep Medicine 14(12): 1334-1340.

[107] Wong, W. S., Lam, H. M. J., Chow, Y. F., Chen, P. P., Lim, H. S., Wong, S., Fielding, R. (2014): The effects of anxiety sensitivity, pain hypervigilance, and pain catastrophizing on quality of life outcomes of patients with chronic pain: a preliminary, cross-sectional analysis. - Quality of Life Research 23(8): 2333-2341.

[108] World Health Organization (WHO) (1999): Guidelines for Community Noise (Berglund, B., Lindvall, T., Schwela, D. H. eds.). - World Health Organization, Geneva.

[109] Xie, H., Kang, J., Mills, G. H. (2009): Clinical review: the impact of noise on patients' sleep and the effectiveness of noise reduction strategies in intensive care units. - Critical Care 13(2): 208.

[110] Yan, D., Hong, T., Dong, B., Mahdavi, A., D’Oca, S., Gaetani, I., Feng, X. (2017): IEA EBC Annex 66: Definition and simulation of occupant behavior in buildings. - Energy and Buildings 156: 258-270.

[111] Zborowsky, T., Kreitzer, M. J. (2008): Creating optimal healing environments in a health care setting. - Minnesota Medicine 91(3): 35-38.

\section{APPENDIX}

Indoor air temperature in the selected hospitals wards in Minna (monthly averages)

\begin{tabular}{|c|c|c|c|c|c|c|c|c|c|c|c|c|c|c|}
\hline Month & Ward & Variables & $\begin{array}{l}6-8 \\
\text { am }\end{array}$ & $\begin{array}{c}8-10 \\
\text { am }\end{array}$ & $\begin{array}{c}10-12 \\
\text { pm }\end{array}$ & $\begin{array}{c}12-2 \\
\text { pm }\end{array}$ & $\begin{array}{l}2-4 \\
\text { pm }\end{array}$ & $\begin{array}{l}\text { 4-6 } \\
\text { pm }\end{array}$ & $\begin{array}{l}\text { 6-8 } \\
\text { pm }\end{array}$ & $\begin{array}{c}8-10 \\
\text { pm }\end{array}$ & $\begin{array}{c}10-12 \\
\text { am }\end{array}$ & $\begin{array}{c}12-2 \\
\text { am }\end{array}$ & $\begin{array}{l}2-4 \\
\text { am }\end{array}$ & $\begin{array}{l}4-6 \\
\text { am }\end{array}$ \\
\hline \multirow{4}{*}{ February } & Surgical & \multirow{4}{*}{$\begin{array}{l}\text { Temp. } \\
\left({ }^{\circ} \mathrm{C}\right)\end{array}$} & 27.9 & 30.9 & 32.9 & 33.8 & 39.7 & 36.8 & 35.1 & 34.4 & 32.6 & 30.6 & 28.7 & 27.9 \\
\hline & Emergency & & 28.0 & 31.8 & 29.4 & 30.7 & 39.2 & 32.3 & 32.1 & 31.4 & 28.4 & 26.6 & 25.7 & 23.7 \\
\hline & Amenity & & 28.5 & 32.1 & 36.9 & 39.9 & 38.7 & 38.4 & 39.4 & 36.3 & 33.1 & 30.0 & 28.2 & 29.4 \\
\hline & Pediatric & & 28.3 & 30.4 & 27.9 & 28.7 & 39.9 & 31.3 & 31.2 & 30.3 & 28.4 & 27.6 & 26.9 & 24.7 \\
\hline
\end{tabular}




\begin{tabular}{c|c|c|c|c|c|c|c|c|c|c|c|c|c|c}
\hline \multirow{4}{*}{ March } & Surgical & & 29.3 & 31.4 & 33.9 & 34.7 & 38.9 & 37.3 & 35.2 & 34.3 & 32.6 & 31.6 & 28.7 & 28.7 \\
& Emergency & Temp. & 29.3 & 31.2 & 33.4 & 34.5 & 39.9 & 37.1 & 35.7 & 34.6 & 32.9 & 30.9 & 28.9 & 27.2 \\
& Amenity & $\left({ }^{\circ} \mathrm{C}\right)$ & 29.3 & 31.7 & 32.8 & 34.2 & 39.5 & 36.8 & 36.7 & 34.4 & 32.5 & 31.9 & 29.1 & 28.2 \\
& Pediatric & & 29.3 & 31.5 & 33.6 & 35.2 & 39.7 & 37.5 & 35.9 & 33.9 & 29.3 & 31.7 & 28.6 & 28.2 \\
\hline \multirow{5}{*}{ April } & Surgical & & 28.9 & 31.7 & 32.9 & 35.2 & 40.7 & 38.4 & 36.4 & 35.3 & 33.1 & 31.0 & 28.2 & 27.4 \\
& Emergency & Temp. & 29.9 & 31.9 & 32.6 & 35.9 & 39.7 & 37.1 & 35.4 & 33.3 & 31.1 & 32.0 & 28.4 & 28.2 \\
& Amenity & $\left.{ }^{\circ} \mathrm{C}\right)$ & 28.3 & 30.8 & 31.9 & 35.7 & 38.9 & 38.3 & 36.2 & 34.3 & 32.1 & 31.4 & 28.1 & 27.1 \\
& Pediatric & & 28.9 & 31.1 & 32.7 & 35.9 & 38.7 & 37.4 & 35.4 & 35.1 & 33.1 & 31.0 & 28.2 & 26.4 \\
\hline
\end{tabular}

Relative humidity in the selected hospitals wards in Minna (monthly averages)

\begin{tabular}{c|c|l|c|c|c|c|c|c|c|c|c|c|c|c}
\hline \multirow{2}{*}{ Month } & Ward & Variables & $\begin{array}{c}\mathbf{6}-\mathbf{8} \\
\mathbf{a m}\end{array}$ & $\begin{array}{c}\mathbf{8 - 1 0} \\
\mathbf{a m}\end{array}$ & $\begin{array}{c}\mathbf{1 0 - 1 2} \\
\mathbf{p m}\end{array}$ & $\begin{array}{c}\mathbf{1 2 - 2} \\
\mathbf{p m}\end{array}$ & $\begin{array}{c}\mathbf{2 - 4} \\
\mathbf{p m}\end{array}$ & $\begin{array}{c}\mathbf{4 - 6} \\
\mathbf{p m}\end{array}$ & $\begin{array}{c}\mathbf{6 - 8} \\
\mathbf{p m}\end{array}$ & $\begin{array}{c}\mathbf{8 - 1 0} \\
\mathbf{p m}\end{array}$ & $\begin{array}{c}\mathbf{1 0 - 1 2} \\
\mathbf{a m}\end{array}$ & $\begin{array}{c}\mathbf{1 2 - 2} \\
\mathbf{a m}\end{array}$ & $\begin{array}{c}\mathbf{2 - 4} \\
\mathbf{a m}\end{array}$ & $\begin{array}{c}\mathbf{4 - 6} \\
\mathbf{a m}\end{array}$ \\
\hline \multirow{5}{*}{ February } & Surgical & & 58.3 & 52.1 & 47.2 & 42.6 & 44.4 & 48.4 & 50.1 & 55.5 & 60.2 & 68.3 & 62.1 & 61.1 \\
& Emergency & \multirow{3}{*}{ R.H. (\%) } & 54.0 & 53.8 & 47.1 & 42.2 & 44.2 & 47.3 & 51.1 & 56.1 & 61.4 & 67.6 & 63.7 & 61.2 \\
& Amenity & & 54.2 & 51.1 & 47.5 & 41.9 & 44.7 & 47.4 & 51.4 & 56.3 & 61.1 & 68.0 & 63.2 & 61.6 \\
& Pediatric & & 55.1 & 54.4 & 47.7 & 41.7 & 44.9 & 47.3 & 51.2 & 56.3 & 61.5 & 67.4 & 63.4 & 61.9 \\
\hline \multirow{5}{*}{ March } & Surgical & & 57.3 & 52.4 & 48.9 & 41.7 & 43.9 & 41.3 & 51.2 & 54.3 & 61.6 & 67.6 & 64.7 & 61.4 \\
& Emergency & \multirow{3}{*}{ R.H. (\%) } & 57.7 & 53.2 & 48.4 & 41.5 & 43.6 & 42.1 & 51.7 & 54.6 & 60.9 & 68.2 & 64.9 & 62.5 \\
& Amenity & 57.6 & 52.7 & 48.8 & 42.2 & 43.5 & 42.5 & 51.6 & 55.4 & 61.5 & 67.9 & 65.1 & 62.5 \\
& Pediatric & & 57.9 & 51.5 & 49.1 & 41.2 & 43.7 & 42.3 & 51.9 & 54.9 & 61.3 & 67.7 & 64.6 & 62.1 \\
\hline \multirow{5}{*}{ April } & Surgical & & 58.6 & 52.7 & 48.9 & 41.2 & 45.5 & 42.4 & 51.4 & 50.3 & 59.5 & 67.0 & 64.2 & 63.8 \\
& Emergency & \multirow{3}{*}{ R.H. (\%) } & 58.2 & 52.9 & 48.6 & 41.9 & 45.5 & 42.1 & 51.4 & 50.3 & 60.1 & 67.5 & 64.4 & 63.7 \\
& Amenity & 58.3 & 52.8 & 47.9 & 41.7 & 45.2 & 42.3 & 51.2 & 50.3 & 59.9 & 67.4 & 64.1 & 63.9 \\
& Pediatric & & 58.7 & 52.1 & 47.7 & 41.5 & 45.1 & 42.4 & 51.4 & 50.1 & 60.1 & 67.8 & 64.2 & 64.3 \\
\hline
\end{tabular}

Noise level in the selected hospital wards in Minna (monthly averages)

\begin{tabular}{c|c|c|c|c|c|c|c|c|c|c|c|c|c|c}
\hline \multirow{2}{*}{ Month } & Ward & \multirow{2}{*}{ Variables } & $\begin{array}{c}\mathbf{6 - 8} \\
\mathbf{a m}\end{array}$ & $\begin{array}{c}\mathbf{8 - 1 0} \\
\mathbf{a m}\end{array}$ & $\begin{array}{c}\mathbf{1 0 - 1 2} \\
\mathbf{p m}\end{array}$ & $\begin{array}{c}\mathbf{1 2 - 2} \\
\mathbf{p m}\end{array}$ & $\begin{array}{c}\mathbf{2 - 4} \\
\mathbf{p m}\end{array}$ & $\begin{array}{c}\mathbf{4 - 6} \\
\mathbf{p m}\end{array}$ & $\begin{array}{c}\mathbf{6 - 8} \\
\mathbf{p m}\end{array}$ & $\begin{array}{c}\mathbf{8 - 1 0} \\
\mathbf{p m}\end{array}$ & $\begin{array}{c}\mathbf{1 0 - 1 2} \\
\mathbf{a m}\end{array}$ & $\begin{array}{c}\mathbf{1 2 - 2} \\
\mathbf{a m}\end{array}$ & $\begin{array}{c}\mathbf{2 - 4} \\
\mathbf{a m}\end{array}$ & $\begin{array}{c}\mathbf{4 - 6} \\
\mathbf{a m}\end{array}$ \\
\hline \multirow{5}{*}{ February } & Surgical & & 26.6 & 47.7 & 52.1 & 58.4 & 60.4 & 60.6 & 58.6 & 47.0 & 44.4 & 35.3 & 30.0 & 27.3 \\
& Emergency & \multirow{3}{*}{ (dBA) } & 27.1 & 48.7 & 53.1 & 60.4 & 62.7 & 61.1 & 59.6 & 49.2 & 46.4 & 34.3 & 31.3 & 28.3 \\
& Amenity & & 28.1 & 47.4 & 49.1 & 61.7 & 64.1 & 62.0 & 50.3 & 48.1 & 46.6 & 34.9 & 31.1 & 28.7 \\
& Pediatric & & 26.3 & 48.6 & 50.7 & 63.2 & 65.7 & 66.1 & 55.3 & 49.3 & 45.1 & 36.4 & 32.2 & 29.3 \\
\hline \multirow{5}{*}{ March } & Surgical & & 26.3 & 47.6 & 58.7 & 66.2 & 69.7 & 64.1 & 58.3 & 49.3 & 46.1 & 39.4 & 31.1 & 27.4 \\
& Emergency & \multirow{3}{*}{ (dBA) } & 26.1 & 48.7 & 57.6 & 68.7 & 69.2 & 65.3 & 56.1 & 48.7 & 45.2 & 36.1 & 32.1 & 26.1 \\
& Amenity & & 25.1 & 49.7 & 56.6 & 68.4 & 69.2 & 68.3 & 58.1 & 50.7 & 44.2 & 35.1 & 31.3 & 29.2 \\
& Pediatric & & 26.1 & 47.9 & 59.6 & 66.7 & 67.2 & 65.3 & 59.1 & 51.7 & 47.2 & 37.1 & 32.4 & 26.2 \\
\hline \multirow{5}{*}{ April } & Surgical & & 26.7 & 47.4 & 59.2 & 68.7 & 62.1 & 63.0 & 58.4 & 49.1 & 41.6 & 39.9 & 36.4 & 27.6 \\
& Emergency & \multirow{2}{*}{ (dBA) } & 28.7 & 49.4 & 58.2 & 66.7 & 62.9 & 64.0 & 60.4 & 51.1 & 43.6 & 37.9 & 34.7 & 28.4 \\
& Amenity & & 29.3 & 48.6 & 58.7 & 68.2 & 64.7 & 66.1 & 59.3 & 48.3 & 44.1 & 38.4 & 35.1 & 27.1 \\
& Pediatric & & 27.7 & 48.9 & 59.2 & 69.7 & 66.1 & 68.0 & 58.4 & 49.1 & 45.6 & 39.9 & 35.4 & 27.6 \\
\hline
\end{tabular}

Light intensity level in the selected hospital wards in Minna (monthly averages)

\begin{tabular}{c|c|c|c|c|c|c|c|c|c}
\hline Month & Ward & Variables & $\mathbf{6 - 8} \mathbf{~ a m}$ & $\mathbf{8 - 1 0} \mathbf{~ a m}$ & $\mathbf{1 0 - 1 2} \mathbf{~ p m}$ & $\mathbf{1 2 - 2} \mathbf{~ p m}$ & $\mathbf{2 - 4} \mathbf{~ p m}$ & $\mathbf{4 - 6} \mathbf{~ p m}$ & $\mathbf{6 - 8} \mathbf{~ p m}$ \\
\hline \multirow{2}{*}{ February } & Surgical & \multirow{2}{*}{$(\mathrm{lux})$} & 296 & 300 & 336 & 380 & 470 & 442 & 310 \\
& Emergency & & 300 & 305 & 340 & 381 & 500 & 451 & 332 \\
\cline { 2 - 9 }
\end{tabular}




\begin{tabular}{c|c|l|l|l|l|l|l|l|l}
\hline & Amenity & & 307 & 310 & 342 & 387 & 510 & 462 & 341 \\
& Pediatric & & 315 & 320 & 351 & 392 & 520 & 466 & 354 \\
\hline \multirow{5}{*}{ March } & Surgical & & 303 & 310 & 388 & 383 & 495 & 471 & 311 \\
& Emergency & \multirow{4}{*}{ (lux) } & 280 & 289 & 367 & 385 & 505 & 473 & 312 \\
& Amenity & & 285 & 291 & 359 & 372 & 506 & 480 & 313 \\
& Pediatric & & 266 & 273 & 369 & 366 & 508 & 462 & 315 \\
\hline \multirow{6}{*}{ April } & Surgical & & 306 & 310 & 388 & 380 & 495 & 465 & 310 \\
& Emergency & \multirow{4}{*}{ (lux) } & 291 & 299 & 399 & 385 & 505 & 475 & 312 \\
& Amenity & & 300 & 305 & 395 & 386 & 500 & 478 & 313 \\
& Pediatric & & 309 & 315 & 405 & 390 & 510 & 480 & 325 \\
\hline
\end{tabular}

Level of $\mathrm{CO}_{2}$ concentration in the selected hospital wards in Minna (monthly averages)

\begin{tabular}{|c|c|c|c|c|c|c|c|c|c|c|c|c|c|c|}
\hline Month & Ward & Variables & $\begin{array}{l}6-8 \\
\text { am }\end{array}$ & $\begin{array}{c}8-10 \\
\text { am }\end{array}$ & $\begin{array}{c}10-12 \\
\text { pm }\end{array}$ & $\begin{array}{c}12-2 \\
\text { pm }\end{array}$ & $\begin{array}{l}2-4 \\
\text { pm }\end{array}$ & $\begin{array}{l}4-6 \\
\text { pm }\end{array}$ & $\begin{array}{l}6-8 \\
\text { pm }\end{array}$ & $\begin{array}{c}8-10 \\
\text { pm }\end{array}$ & $\begin{array}{c}10-12 \\
\text { am }\end{array}$ & $\begin{array}{c}12-2 \\
\text { am }\end{array}$ & $\begin{array}{l}2-4 \\
\text { am }\end{array}$ & $\begin{array}{l}4-6 \\
\text { am }\end{array}$ \\
\hline \multirow{4}{*}{ February } & Surgical & \multirow{4}{*}{ (ppm) } & 520 & 600 & 686 & 710 & 680 & 512 & 580 & 470 & 450 & 390 & 330 & 310 \\
\hline & Emergency & & 530 & 605 & 690 & 721 & 640 & 531 & 450 & 482 & 445 & 385 & 328 & 271 \\
\hline & Amenity & & 535 & 610 & 692 & 730 & 640 & 542 & 435 & 461 & 412 & 377 & 316 & 260 \\
\hline & Pediatric & & 538 & 620 & 701 & 750 & 665 & 586 & 427 & 484 & 434 & 367 & 321 & 285 \\
\hline \multirow{4}{*}{ March } & Surgical & \multirow{4}{*}{ (ppm) } & 518 & 610 & 698 & 723 & 675 & 521 & 471 & 462 & 452 & 388 & 325 & 258 \\
\hline & Emergency & & 513 & 608 & 687 & 733 & 645 & 533 & 461 & 475 & 440 & 397 & 320 & 264 \\
\hline & Amenity & & 522 & 612 & 695 & 725 & 641 & 548 & 440 & 458 & 431 & 382 & 313 & 280 \\
\hline & Pediatric & & 519 & 627 & 709 & 740 & 668 & 589 & 433 & 477 & 441 & 375 & 316 & 272 \\
\hline \multirow{4}{*}{ April } & Surgical & \multirow{4}{*}{ (ppm) } & 515 & 610 & 678 & 703 & 650 & 485 & 440 & 430 & 422 & 360 & 310 & 290 \\
\hline & Emergency & & 511 & 615 & 674 & 711 & 610 & 515 & 435 & 422 & 428 & 350 & 307 & 275 \\
\hline & Amenity & & 518 & 605 & 685 & 715 & 625 & 508 & 445 & 433 & 412 & 345 & 303 & 298 \\
\hline & Pediatric & & 516 & 621 & 673 & 700 & 638 & 520 & 405 & 415 & 410 & 330 & 301 & 281 \\
\hline
\end{tabular}

